\title{
Effect of Soil Types on The Development of Matric Suction and Volumetric Water Content for Dike Embankment During Overtopping Tests
}

\author{
Marwan Adil Hassan ${ }^{a}$, Mohd Ashraf Mohamad Ismail ${ }^{b^{*}}$ \\ ${ }^{a}$ Ph.D. Student, School of Civil engineering, Universiti Sains Malaysia, Engineering Campus, 14300 Nibong Tebal, Pulau Pinang, Malaysia. \\ ${ }^{b}$ Senior Lecturer, School of Civil engineering, Universiti Sains Malaysia, Engineering Campus ,14300 Nibong Tebal, Pulau Pinang, Malaysia.
}

Received 14 February 2018; Accepted 30 March 2018

\begin{abstract}
The resistance of dike materials has a great effect on the development of hydraulic engineering around the world. It helps to understand the mechanism of dike failure occurred due to the influence of hydraulics and Geotechnical parameters. The overtopping moment is one of the main failures that reduces the stability of the dike embankment through initiating the breach channel inside dike crest as a result of water flow above the downstream slope of the dike. Two spatial overtopping tests were conducted at in Hydraulic Geotechnical laboratories at the University Sains of Malaysia to observe the evolution of matric suction and volumetric water content for two soil types of sand and very silty sand soils. A pilot channel was cut in dike crest along the side wall of the small flume channel to represent the transition water flow from upstream into downstream slopes during overtopping test. The results indicated that the matric suction decreases due to the increase of volumetric water content during the saturation of dike body. The proportion increasing and decreasing of volumetric water content and matric suction is lower in very silty sand than those in sand soil due to the presence of fine particles in previous soil.
\end{abstract}

Keywords: Dike; Matric Suction; Volumetric Water Content; Overtopping Failure; Spatial Breach Test.

\section{Introduction}

The construction of dike embankment has an essential situation in developing the areas of hydraulics and civil engineering. It is constructed from an earthfill materials to prevent most dangerous failures such as sliding and overtopping [1] and also save people's lives and property through preserving water in front of dike construction [2] and [3]. Different hydraulics and Geotechnical situations are exposed to dike embankment and thus causes failure inside the dike body for both saturated and unsaturated soil conditions [4]. A South Dark earthfill dam collapsed in 1889 in the USA due to overtopping failure. The duration of overtopping failure is continued for 3.5 hours and caused losses of 2200 human lives. Many earthfill dams were damaged due to the development of the breach channel inside dam's bodies during last century, such as Orós, Babi Yar, Sempor and Machhu II in Brazil, USSR, Indonesia and India, respectively. The majority of the dam and dike failures, with their causes and effects on losses of peoples' lives, are included in many research studies [5-7]. The overtopping failure is occurring due to overflowing water above dike crest into downstream slope and occurred as a result of different conditions such as high water level and the change of bed level [8] as well as the extreme hydrology conditions [9], inadequate rehabilitation works [10] and the efficiency of spillway design [11]. The breach channel failure, due to overtopping moment, has occurred as a result of unsuitable design of spillway, the spillway blocked, the losses of storage capacity of dike and higher soil displacement due to earthquake failure [12]. The

* Corresponding author: ceashraf@usm.my

$>$ This is an open access article under the CC-BY license (https://creativecommons.org/licenses/by/4.0/).

(C) Authors retain all copyrights. 
dike failure is dominant controlled by the erosion process occurred in the downstream and upstream slopes while the reservoir water on the upstream slope, dike materials and installation effect on dike stability. The compaction of dike materials inside flume channels is widely studied by researchers as laboratory tests [13] as well as through software models [14-16]. The experimental tests included the evaluation of breach channel for non-cohesive [17] and cohesive materials [18] as well as for both homogeneous and composite soil materials during overtopping failure [19]. The compaction of non-cohesive materials are controlled through using vibratory and static loads. However, the simulation between prototype and laboratory experiments is difficult due to the differences in possibilities for laboratory conditions [20].The resistance of non-cohesive dike embankment against the overtopping failure is more stable during the compaction method of standard proctor minimum higher than compaction with efforts of (85-92\% Proctor optimum) [21]. In 1990, a Series of overtopping tests were conducted by the U.S. Department of Agriculture (USDA) Agricultural Research Service Hydraulic Engineering Research Unit to observe the erosion process in the dike embankment of grass covered in dike channel. They found that the grass reduced the rate of erosion process in during overtopping tests [22]. Three different overtopping tests, with different water contents, were performed by the USDA ARSHERU to analyze the behavior of erosion process during Phase II and III of earth embankments [23]. The spatial breach tests were simulated through initiating notch cut in the dike crest. The results indicated that the instability of dike slope is caused by the undercutting of the breach channel as a result of overflowing water above the downstream and upstream slopes and thus resulted in a huge amount of eroded materials along the dike's bed channel [24] and [25]. These observations are similar to the notification results of [26].

A total of twenty four dike models were constructed by the Department of Civil Engineering, University of KwaZuluNatal in Durban, South Africa to determine the breach channel process inside sand barrier with the assistance of a video camera to evaluate the evolution of water level [27] and [28]. The overtopping flow is crossed above dike crest into the downstream slope through $\mathrm{V}$ - notch. They observed two types of dike failure during the tests. The first one, called as initiation phase, initiated at the base of the downstream slope in which dike materials are eroded through channel while the second one called a formation phase. The dike crest is collapsing while the lateral and vertical erosion processes are taking place in the downstream and upstream slope. At the end of tests, A Venturi or hourglass shape for the dike breach profile is viewed due to pore water pressure in dike slope [29]. The author has investigated the effect of inflow discharges on the development of negative pore water pressure and water content inside the sand embankment dike during spatial overtopping tests. Two sensors of tensiometer and Time Domain Reflectometer were used to measure the responses of the sand dike for water saturation. He observed that the higher inflow discharges increased the volumetric water content faster than that for lower inflow discharges. This is due to the increasing water velocity during the development of erosion process inside dike [30]. The effects of dike slopes on the development of matric suctions and volumetric water contents are determined through a series of spatial overtopping tests. Two dike slopes of $1 \mathrm{~V}: 3 \mathrm{H}$ and $1 \mathrm{~V}: 2.5 \mathrm{H}$ were used to evaluate the responses of sand embankments through the infiltration of water level from the upstream slope into the downstream slope. A pilot channel was cut in the dike crest along the side wall of the flume channel to initiate the breach channel. The authors have observed that the percentages increasing of water content are higher for slope of $1 \mathrm{~V}: 3 \mathrm{H}$ than the other slope prior to overtopping failure and vice versa after the overtopping moment. This is due to the increasing of erosion process rate inside breach channel and thus accelerate the decreasing of negative pore water pressures [31]. In this study, two spatial overtopping tests were conducted in Hydraulic Geotechnical laboratories at the Universiti Sains to evaluate the development of matric suction (negative pore water pressure) and volumetric water content through using tensiometer and Time Domain Reflectometer (TDR) sensors, respectively of six groups for sandy and very silty sand soil.

\section{Experimental Test Procedures}

Up to two spatial overtopping tests of dike embankment are installed as a trapezoidal shape to predict the responses of matric suctions and volumetric water contents. The dike soil is classified as poorly graded coarse sand while the other soil is classified as low plasticity of very silty sand while the Atterberg Limit tests are conducted in accordance with BS 1377: Part 2: 1990 as shown in Tables 1 and 2, respectively. The dikes are constructed at the end of the small flume channel with dimensions of $190 \mathrm{~cm}$ length, $50 \mathrm{~cm}$ width and $30 \mathrm{~cm}$ height on the operation of overtopping failure. Both of upstream and downstream slopes are constants with 1V:3H under inflow discharges of 30 1/min. These dimensions are kept constants during the spatial overtopping tests. The small flume channel is constructed especially for simulating the performance of dike embankment during the infiltration of water level with dimensions of 450,50 , and $60 \mathrm{~cm}$ for length, width, and height, respectively as shown in Figure 1. The phreatic water level is attached the dike crest and then transmitted into the downstream slope through initiating a pilot channel along the side wall of the flume channel with dimensions of $3 \mathrm{~cm}$ height and $4 \mathrm{~cm}$ width as shown in Figure 2. Twelve sensors of Tensiometer and TDR are installed on the side wall of flume channel and inside dike materials for measuring the matric suction and volumetric water content, respectively. This tensiometer sensor, of higher accuracy $\pm 0.1 \% \mathrm{v}$., is consisted of the pressure transducer and a porous ceramic cup. The pressure transducer, connected to a data logger, was developed instead of the vacuum dial gauge. This is due to its ability for continuous, automatic and systematic recording of the suction. The type of the tensiometer for this study is $2100 \mathrm{~F}$ Soil moisture Probe and the transducer model is 5301. The current transduced pressure required a power supply of $12-40 \mathrm{~V}$ dc. The assembly transiometer-transducer pressure should be covered with 
watertight seal for insuring the sensitivity of the instruments. The calibration process of tensiometer-transducer instrument is done through connecting the long part of the assembly with data logger of an integrated direct current power supply. For calibration process, the de-air water was used to fill the tensiometer and get out the water bubbles from tensiometer. The time needed to reach the equilibrium state is rounded between 1 to 5 min depending on the condition surrounding the ceramic cup. The minimum and maximum matric suction that tensiometer-transducer assembly could achieved is between 0 to $90 \mathrm{kPa}$ which is suitable for spatial overtopping tests. A Time Domain Reflectometer (TDR) system of Trime-pico 32 manufactured at IMKO Micromodultechnic GmbH is installed on the side wall of the PVC flume channel. The accuracy Of Trime-Pico 32 is high with (₹1) picosecond. It is consisted of TDR probes, power supply adapter, a distribution module and a GlobeLog datalogger. This type of TDR has used to measure water content, soil temperature and electrical conductivity and salt content. The dimension of TDR body is 155 $\mathrm{mm}$ length and $32 \mathrm{~mm}$ diameter. It is connected to two rods of $110 \mathrm{~mm}$ length and 3.5. The 32 Trime-pico is supplied electricity from an external 7-24V/DC power supply and connected to the IMKO GlobeLog data logger for continuous and automatic data recording. The locations of tensiometer and TDR sensors are dependent on the directions of erosion process inside dike embankment.

Table 1. Sieve analysis test for sandy soil

\begin{tabular}{|c|c|c|c|c|c|}
\hline \multicolumn{2}{|c|}{ Dike components (\%) } & \multirow{2}{*}{$\begin{array}{c}\text { Parameter }(\mathbf{m m}) \\
\mathrm{D}_{60}=1\end{array}$} & \multirow[t]{2}{*}{$(\mathbf{C u})$} & \multirow[t]{2}{*}{ (Cc) } & \multirow[t]{2}{*}{ Soil Classification } \\
\hline Sand & 80.59 & & & & \\
\hline Gravel & 19.10 & $\mathrm{D}_{30}=0.58$ & \multirow[t]{2}{*}{3.03} & \multirow[t]{2}{*}{1.019} & \multirow[t]{2}{*}{ SP } \\
\hline Silt \&Clay & 0.31 & $D_{10}=0.33$ & & & \\
\hline
\end{tabular}

Table 2. Sieve analysis test for the very silty sand soil

\begin{tabular}{|c|c|c|c|c|}
\hline \multicolumn{2}{|c|}{ Dike components (\%) } & Liquid limit & Plastic limit & Soil Classification \\
\hline Sand & 60.56 & & & \\
\hline Gravel & 14.35 & 31.5 & 26.6 & SML \\
\hline Silt \&Clay & 25.09 & & & \\
\hline
\end{tabular}

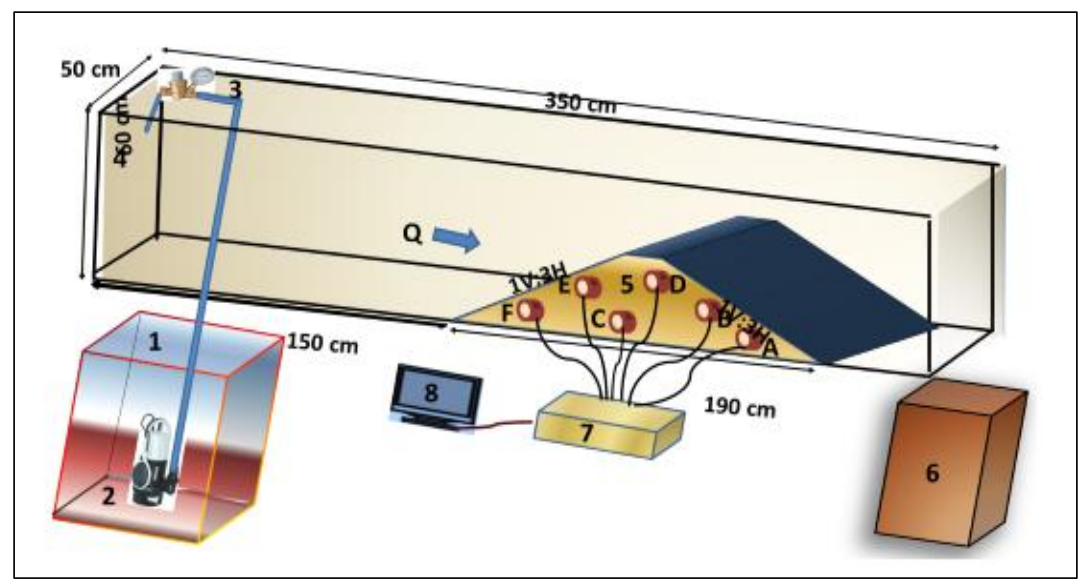

Figure 1. Components of overtopping channel test for: 1) Water tank; 2) Discharge pump; 3) Flowmeter; 4) Flume channel; 5) Dike construction; 6) Sediment tank; 7) Data logger

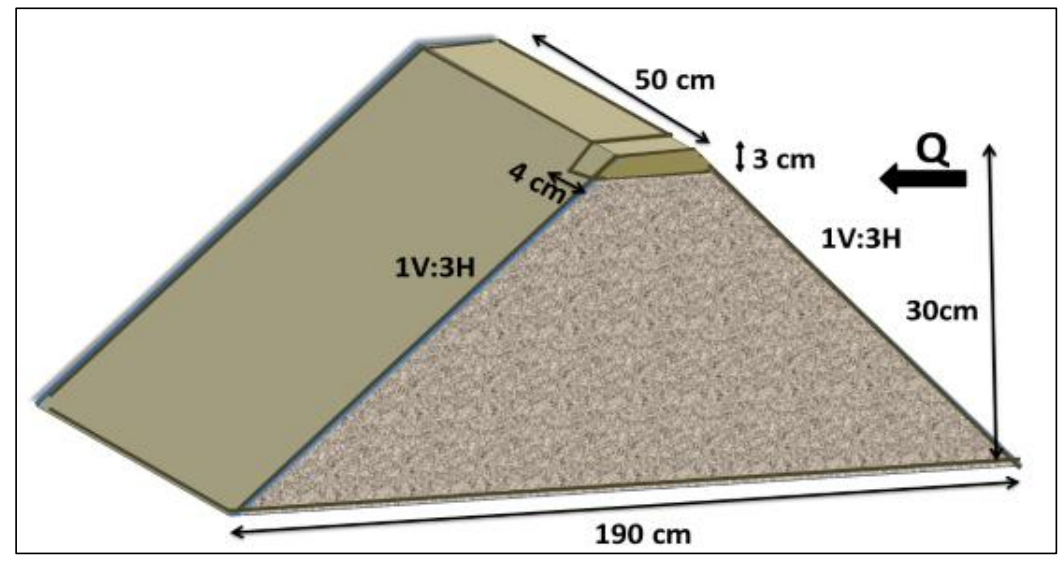

Figure 2. Geometry of dike construction with pilot channel location (shaded area) 
Both of two soils are oven-dried at $105^{\circ} \mathrm{C}$ for 24 hours in order to become in dry condition prior to overtopping tests. The dike material is inserted into layers of $10 \mathrm{~cm}$ with hand timber compaction to evaluate the bulk density of $1.8 \mathrm{~g} / \mathrm{cm}^{3}$ for all the construction. The precise value of bulk density of both soils is essential for results comparison. The flume channel is supplied by Flowmeter and sediment box, to collect the eroded materials, in the beginning and ending of channels, respectively. The tests begin through opening the Flowmeter as fast as possible to obtain a constant inflow discharge of $30 \mathrm{l} / \mathrm{min}$. During the transition of flow water from upstream into downstream slopes, both of tensiometer and TDR sensors are recorded the matric suction and volumetric water content, respectively till the end of experimental tests. The sensors are connected with data logger in which the results are analyzed and showed through P.C. In this study, the results of matric suction and volumetric water contents are drawn by using Origin8 software. The tests ended when the dike materials around each group is removed completely due to erosion processes. In this paper, the terms S1 (Soil 1) and S2 (Soil 2) are used to indicate the experimental results for sandy and very silty sand soils, respectively.

\section{Results and Discussions}

Figures 3 and 4 show the response of matric suction and volumetric water content for each group during overtopping tests for $\mathrm{S} 1$ and $\mathrm{S} 2$, respectively. The $\mathrm{X}$ - axis represents the matric suction $(\mathrm{kPa})$ and volumetric water content $(\%)$ while the Y- axis represents the time of overtopping tests (minutes). In reality, the reservoir water effects on the water flow inside breach channel and thus it is difficult to get the constant value of reservoir flow in front of upstream slope. Nevertheless, the application of the constant inflow of $30 \mathrm{l} / \mathrm{min}$ is suitable for practical uses. For each group sensors, the matric suction is increased in the beginning of overtopping test due to the installation of tensiometer sensors inside dike materials. The records of infiltration air surrounding sensors are increased possessively because of gradually destroying the inter-particle connection inside the dike while the responses of TDR sensors are close to zero due to lack or negligible infiltration of water flow for both S1 and S2. For group F, the decreasing and increasing matric suction and volumetric water content are occurring at $\mathrm{t}=4$ and 9 minutes for S1 and S2, respectively. The matric suction and volumetric water content are $14.45 \mathrm{kPa}$ and $33 \%$ for S1, respectively, while they are $14.63 \mathrm{kPa}$ and $16.8 \%$, respectively for S2. The infiltration water penetrated the soil particles in vertical and horizontal directions. The horizontal water level saturated the horizontal base of dike embankment while the vertical one expelled out the negative pore water pressure and changed soil condition from dry to partial saturated conditions. As a result of water saturation, the matric suction is decreased gradually due to the increasing of volumetric water content and thus reduce the soil shear strength. The vertical soil water pressure transfer infiltration water from lower tension zone to higher tension zone; consequently the meniscus curve "connected between air pressure and water pressure" is destroyed. As most of soil particles saturated in group F, the permeability to air and water flow is decreased and increased, respectively, depending on the proportion of soil components while the vertical water level moved up into other groups in the transition area between upstream and downstream slopes. In group E, the reduction of matric suction occurred at $t=5$ and 10 minutes with values of 14.6 and $13.09 \mathrm{kPa}$ while the volumetric water contents are 27 and $19 \%$ for S1 and S2, respectively. The water infiltration saturates the soil voids near the toe of the upstream slope and thus longer time is needed for saturation process near group F. On the other hand, the presence of earth gravity reduces the water velocity near group E, consequently, the noticeable decreasing and increasing of matric suctions and volumetric water content, respectively are occurring slowly compared with group F. The saturation processes for groups A, B, C and D, in both soils, is similar to that occurred in groups $\mathrm{E}$ and $\mathrm{F}$ in which the movement of water particles is dependent mainly on locations of these groups in middle and downstream slope of dike embankment. The reductions and increasing of negative pore water pressures and volumetric water contents, respectively, for the three groups occurred after overtopping failure due to the development of the breach channel inside the pilot channel in the dike crest. The erosion process of dike materials is faster in the downstream slope and then widened in the transition area between downstream and upstream slope and thus the saturation water process is faster compared with that in groups $\mathrm{E}$ and F. For S1, the reduction and increasing of matric suctions and volumetric water contents for groups $\mathrm{A}, \mathrm{B}, \mathrm{C}$ and $\mathrm{D}$ are occurring at $\mathrm{t}=9,8,10$ and 7 minutes while for $\mathrm{S} 2$, the decreasing of negative pore water pressures for mentioned groups are occurring at $\mathrm{t}=13,10,11$ and 11 minutes, respectively. 


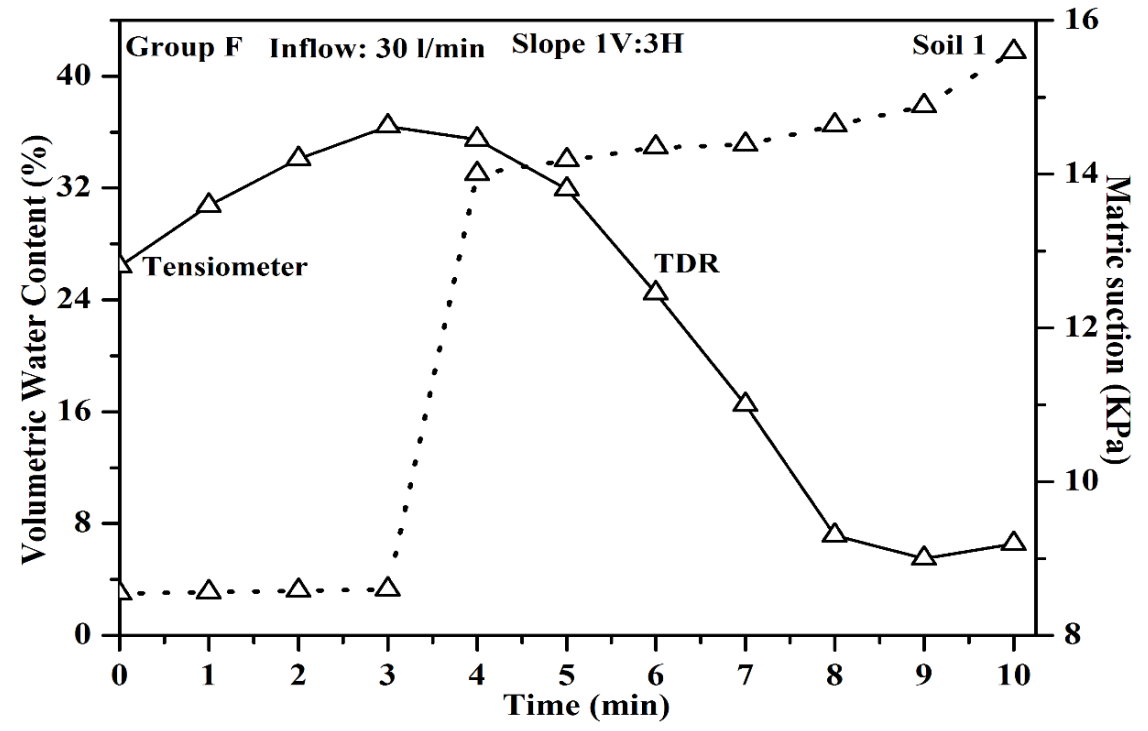

(a)

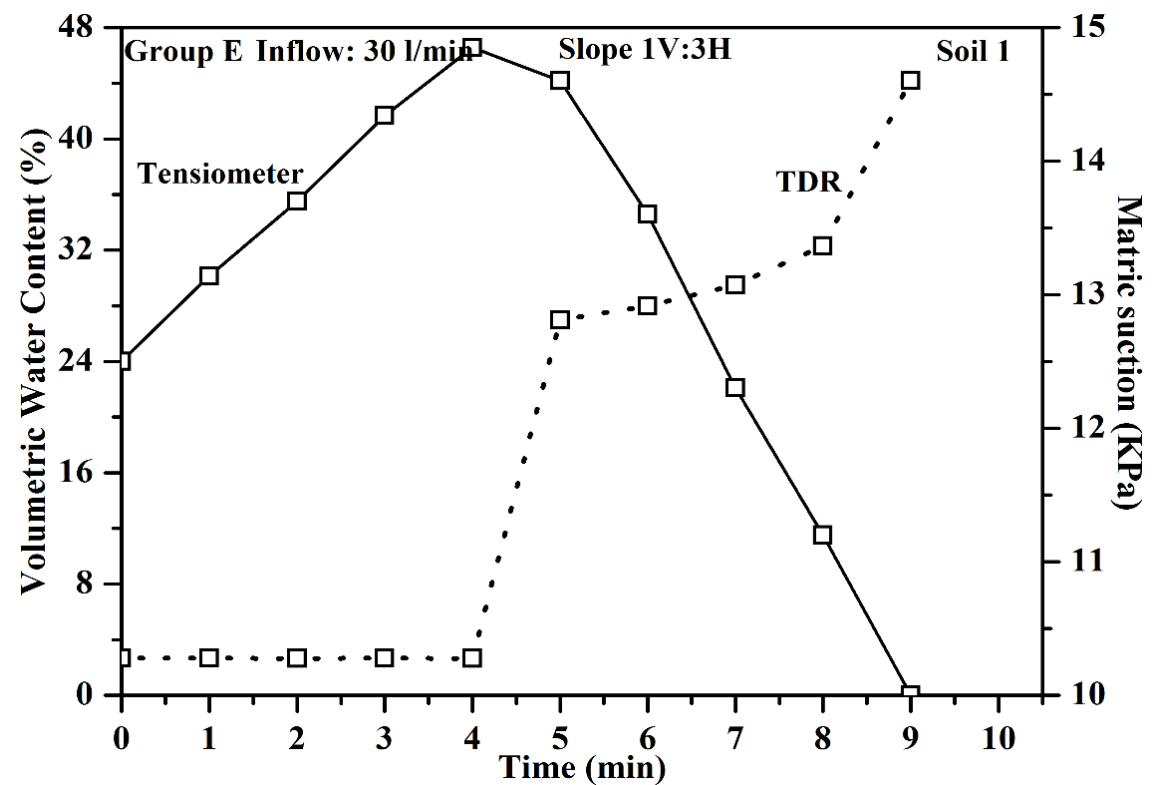

(b)

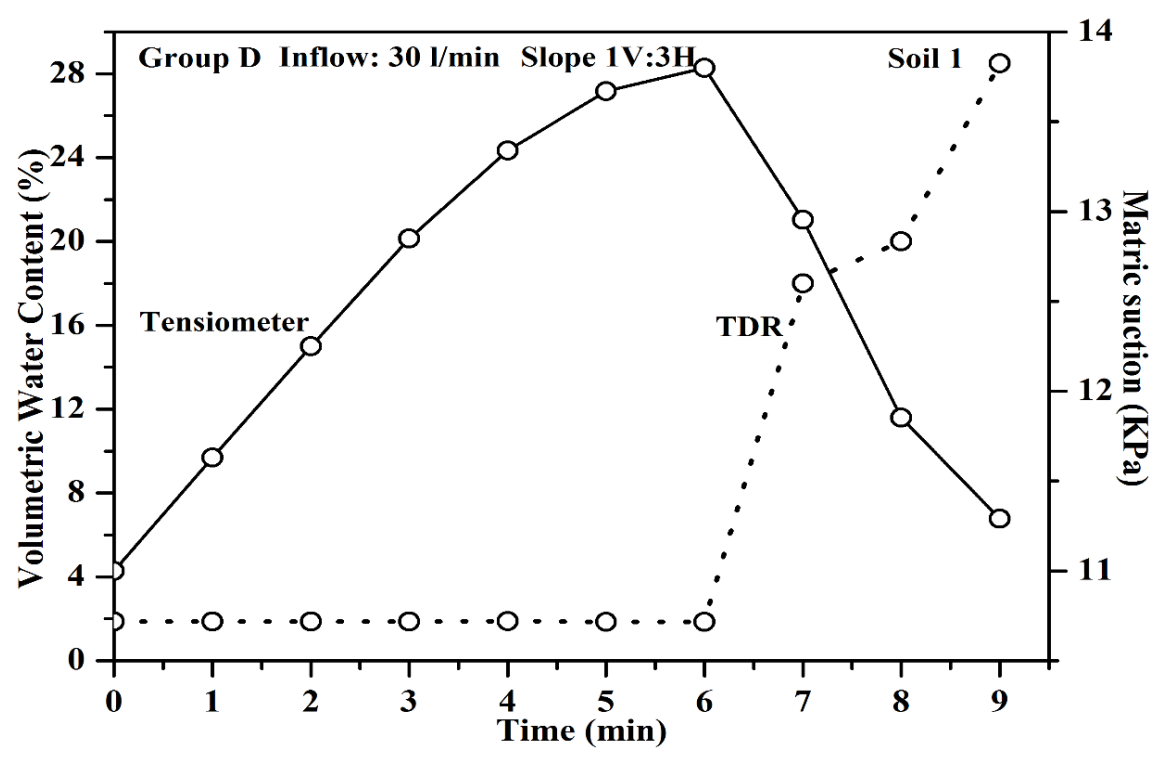

(c) 


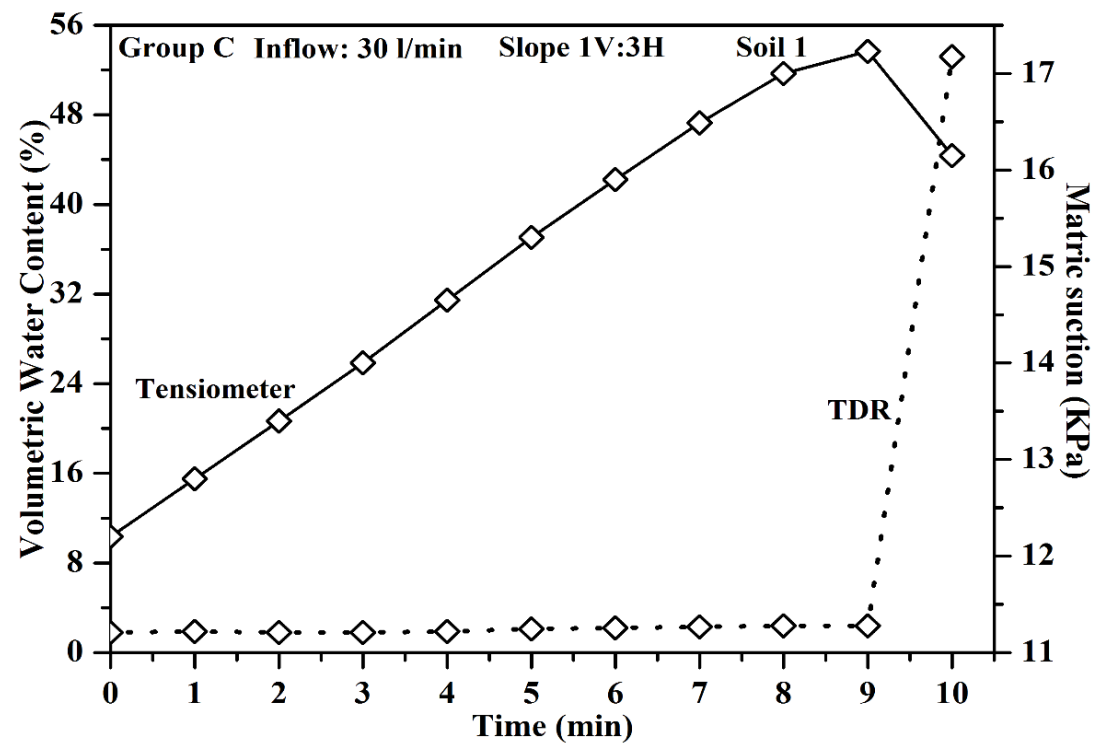

(d)

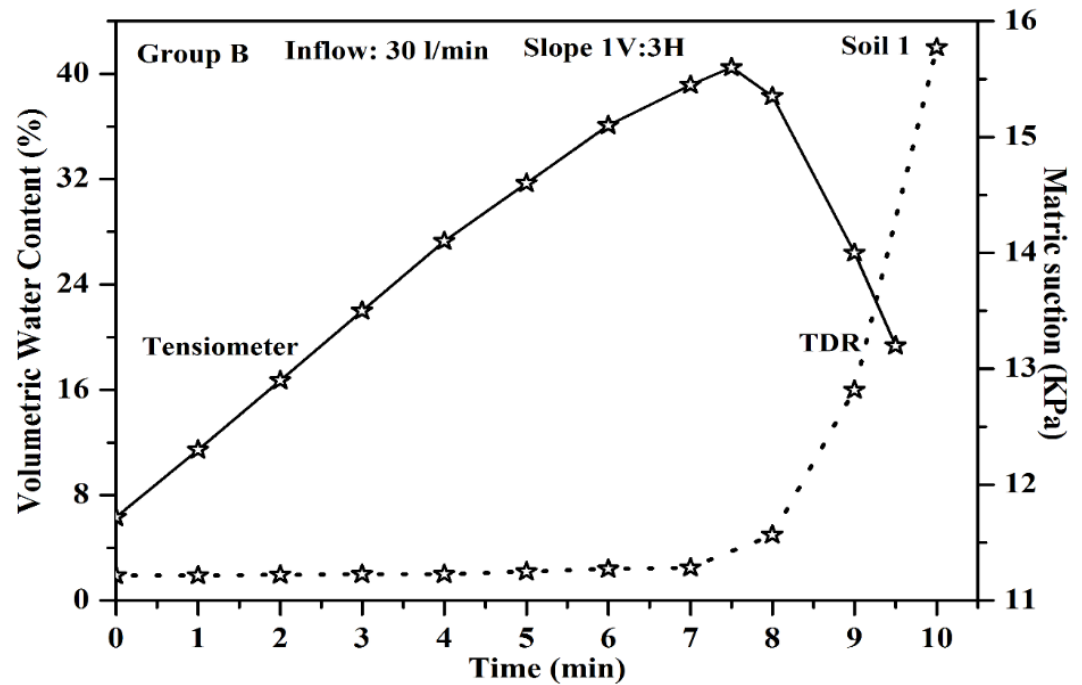

(e)

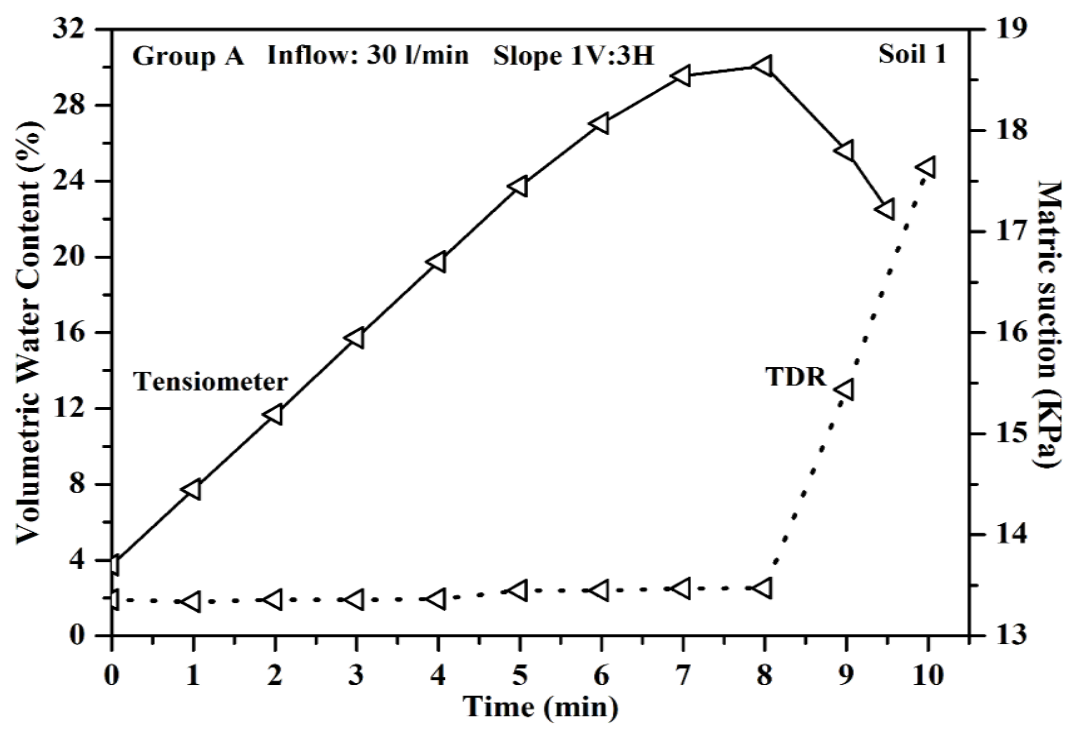

(f)

Figure 3. Response of matric suction and volumetric water content for groups of S1: a) F; b) E; c) D; d) C; e) B; f) A; respectively 


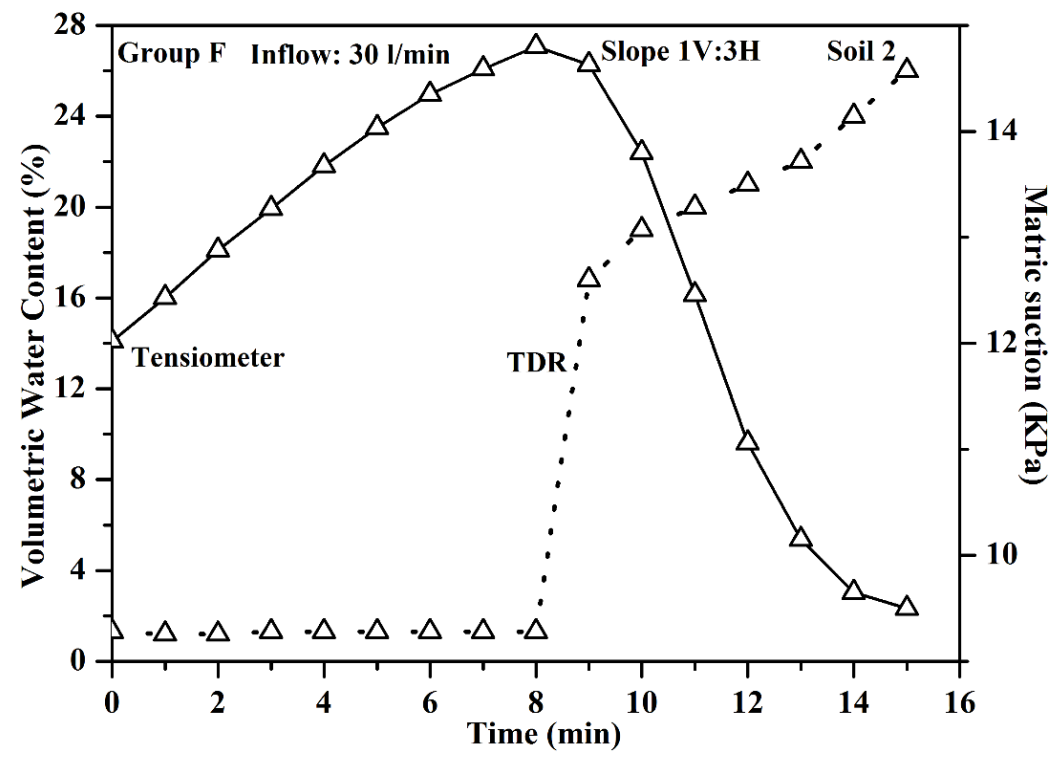

(a)

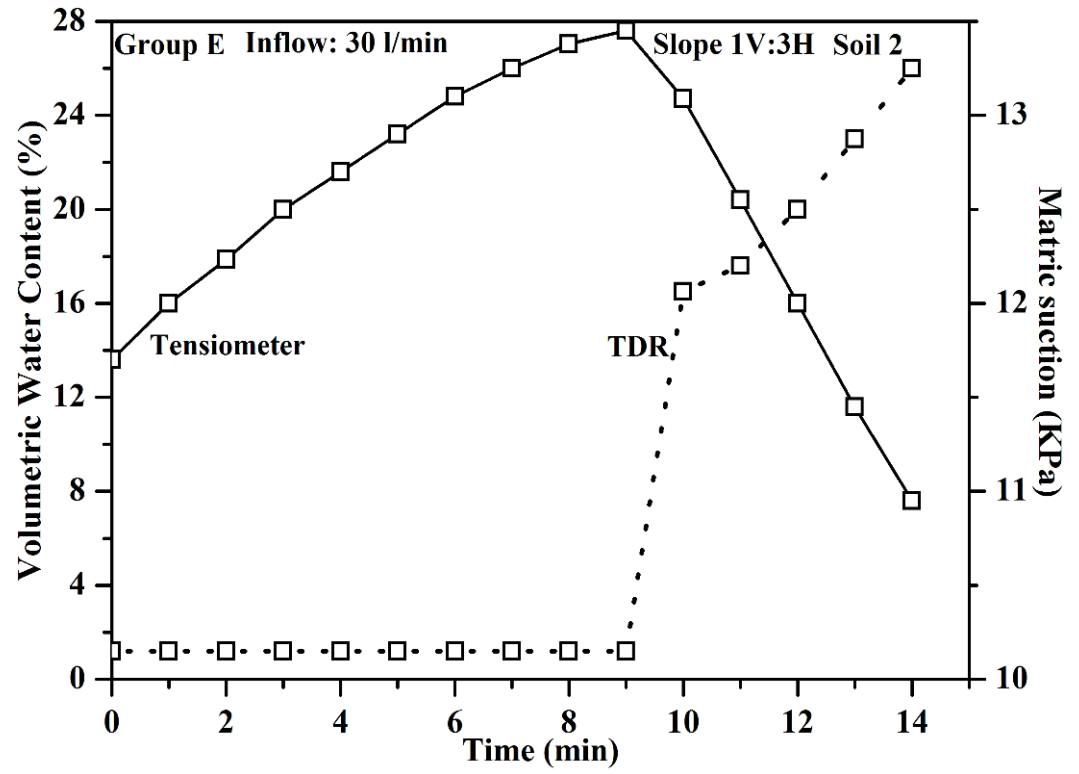

(b)

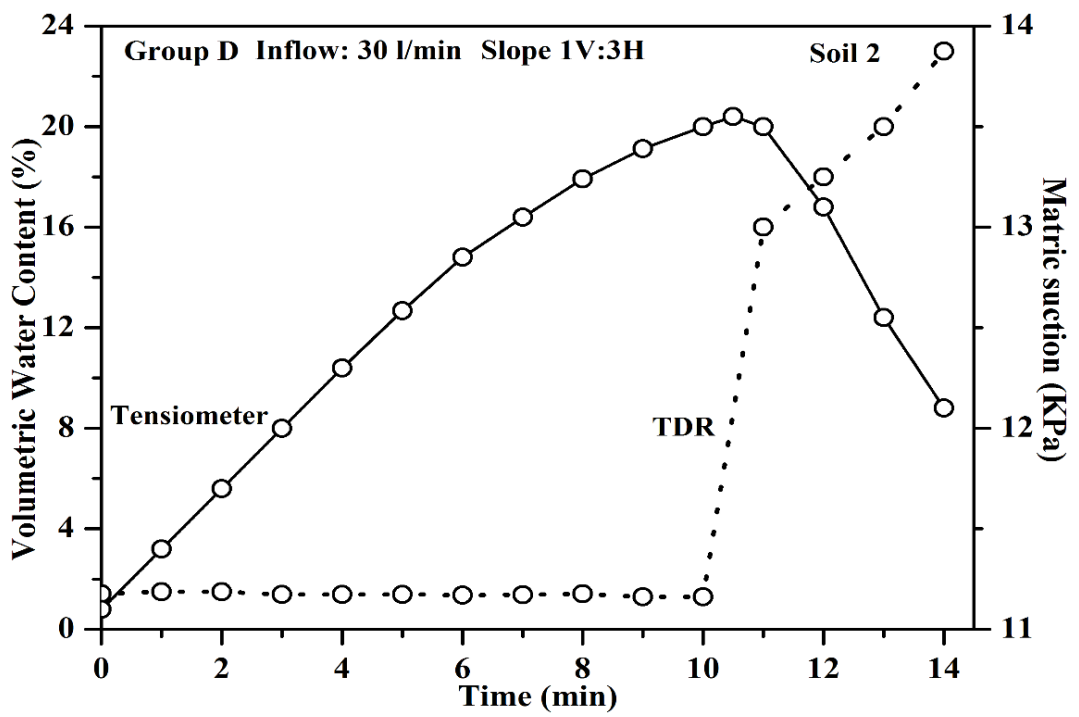

(c) 


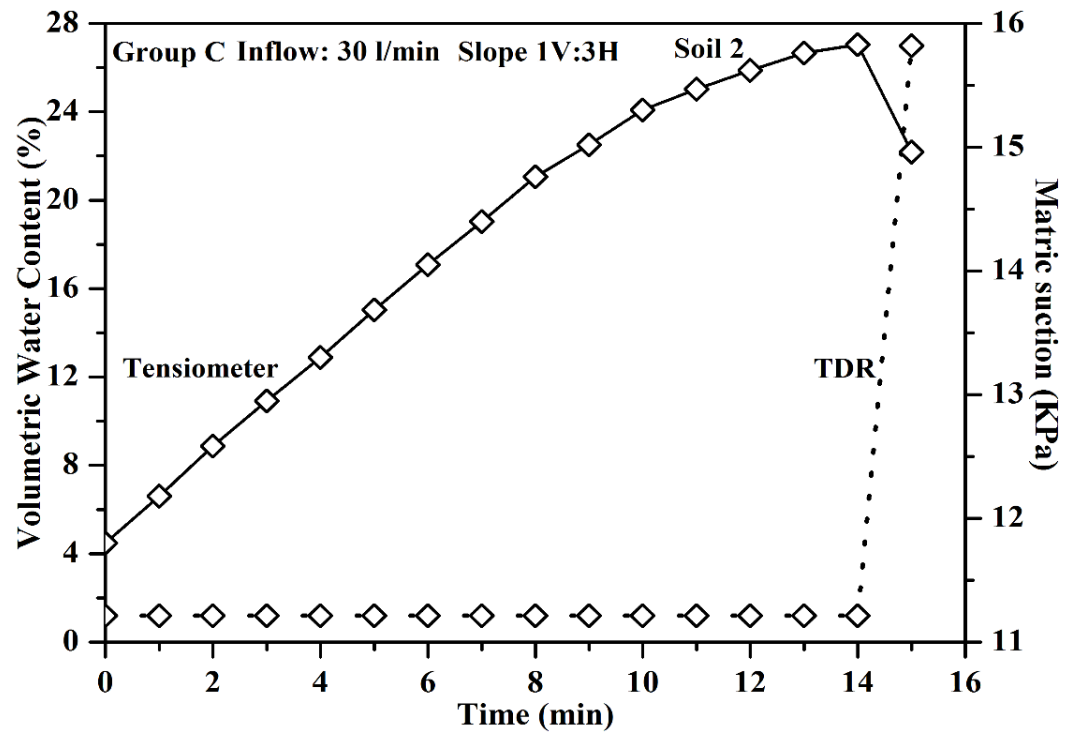

(d)

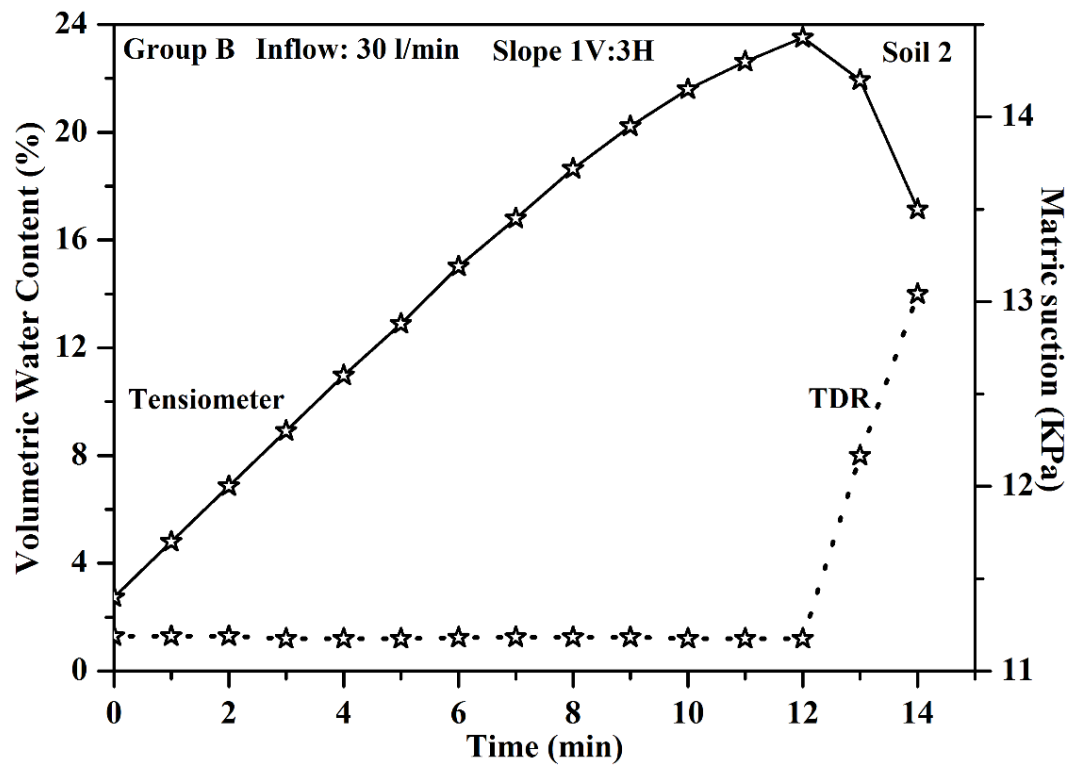

(e)

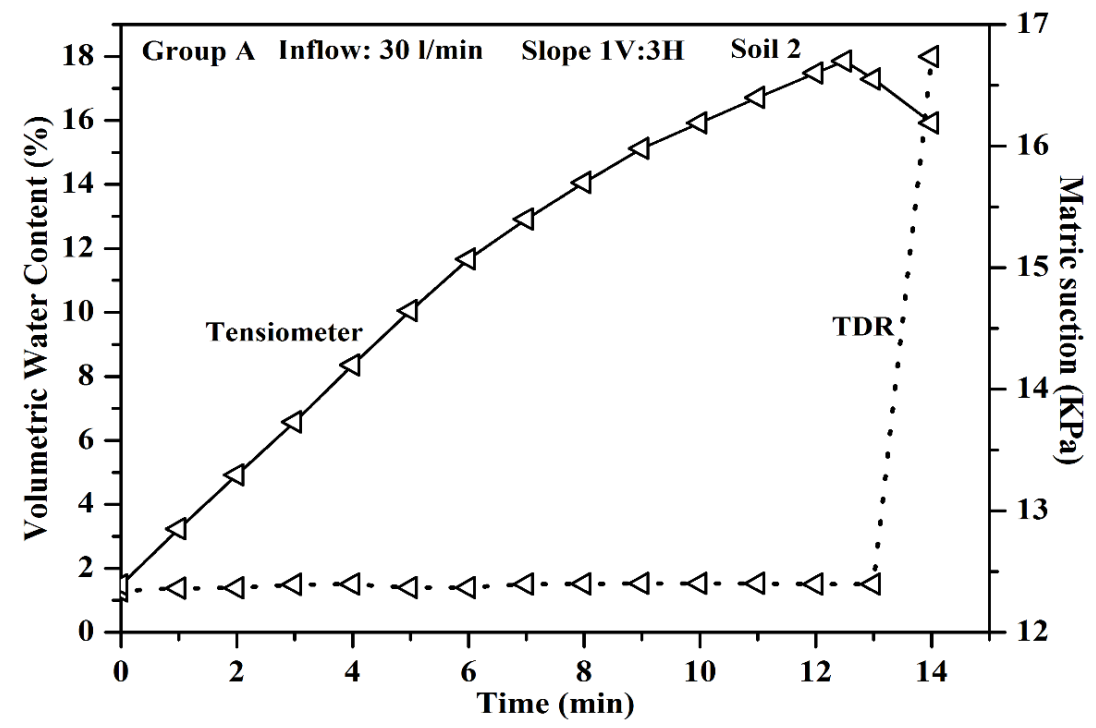

(f)

Figure 4. Response of matric suction and volumetric water content for groups of S2: a) F, b) E, c) D, d) C, e) B, f) A, respectively 
Figure 5 shows the actual procedures of experimental tests during the infiltration of water level prior and after the overtopping failure. It show the installation of dike embankment inside flume channels as well as the locations of tensiometer and TDR sensors that distribute in upstream and downstream slopes. The height of upstream slope is divided into $3,6,9,12,15,18,21,24,27 \mathrm{~cm}$ in order to clarify the gradual water fill up of soil particles. The last height of 27 $\mathrm{cm}$ represents the initiate time of overtopping moment in the dike crest. The infiltration water attached the base of the upstream slope as shown in Figure 5a. During this stage, the particles still have higher negative pore water pressures due to the lack of water content. The phreatic water level starts to increase the percentage of water content faster and thus progressively reduce the resistance of soil shear strength. It is connected the dike heights of 3, 12, 18, 24 and 27 $\mathrm{cm}$ as shown in Figure 5b, 5c, 5d, 5e and 5f, respectively. Figure 6 shows the responses of tensiometer and TDR sensors after the overtopping failure. The overtopping water cross over the pilot channel at $\mathrm{t}=$ zero seconds. The breach channel widen gradually in the downstream slope, the transition area between upstream and downstream slope and then eroded area of upstream slope at $t=20,70,110$ and 190 seconds. This process occurs due to the increasing of water velocity during erosion process and thus rapidly reduce the values of negative pore water pressure for all groups. The last time represented the end of experimental tests in which the erosion process of dike materials is stabilized.

Figures 7 and 8 show the responses of matric suctions and volumetric water contents for all groups during overtopping tests of S1 and S2, respectively. Group F are saturated with infiltration water earlier than group E for both S1 and S2. This is because of starting the decreasing and increasing of matric suction and volumetric water content, respectively near the toe of upstream slope in which phreatic water level is distributed easily in this area due to the small effect of gravity against the movement of infiltration water. For S1, the continuity of saturation process leads to decrease the matric suction for group $\mathrm{F}$ further than that in group $\mathrm{E}$ while the responses of negative pore water pressures are 11 and $12.3 \mathrm{kPa}$, respectively at $\mathrm{t}=7$ minutes. The volumetric water contents are 35.11 and $29.5 \%$, respectively. The percentage of water contents are still occupying the soil particles at latter minutes in which the higher volumetric water content is $41.75 \%$ at $\mathrm{t}=10$ minutes. The same procedures are occurring in the very silty sandy soils in which the reductions and increasing of matric suctions and volumetric water content is faster for group F. The matric suctions are 11.04 and 12 $\mathrm{kPa}$ for groups $\mathrm{F}$ and $\mathrm{E}$, respectively, while the volumetric water contents are 21 and $20 \%$ for groups $\mathrm{F}$ and $\mathrm{E}$ respectively at $\mathrm{t}=12$ minutes. This is because of continuous erosion processes near group F near the bed of dike bed. The completely saturated condition of dike particles is difficult to be reached during overtopping test due to the large particle spaces in the downstream slope. The location of group D, below the dike crest, represents the initiation of breach failure inside pilot channel as a result of the flow water cross above dike crest. The decreasing and increasing of matric suction and volumetric water content, respectively, are occurring before the overtopping moment at $\mathrm{t}=7.16$ and 11.7 minutes for S1 and S2, respectively. The fine particles of the very silty sand tend to store huge amount of water contents, in the upstream slope, inside particles and thus reduces further, compared with sandy soil, the movement of water level towards soil voids near group D. The volumetric water content are 20 and $1.42 \%$ for S1 and S2, respectively at $t=8$ minutes. The differences in the beginning of overtopping moment are occurred due to the presence of fine particles in $\mathrm{S} 2$ in which it resulted in decreasing the velocity of water level near dike crest.
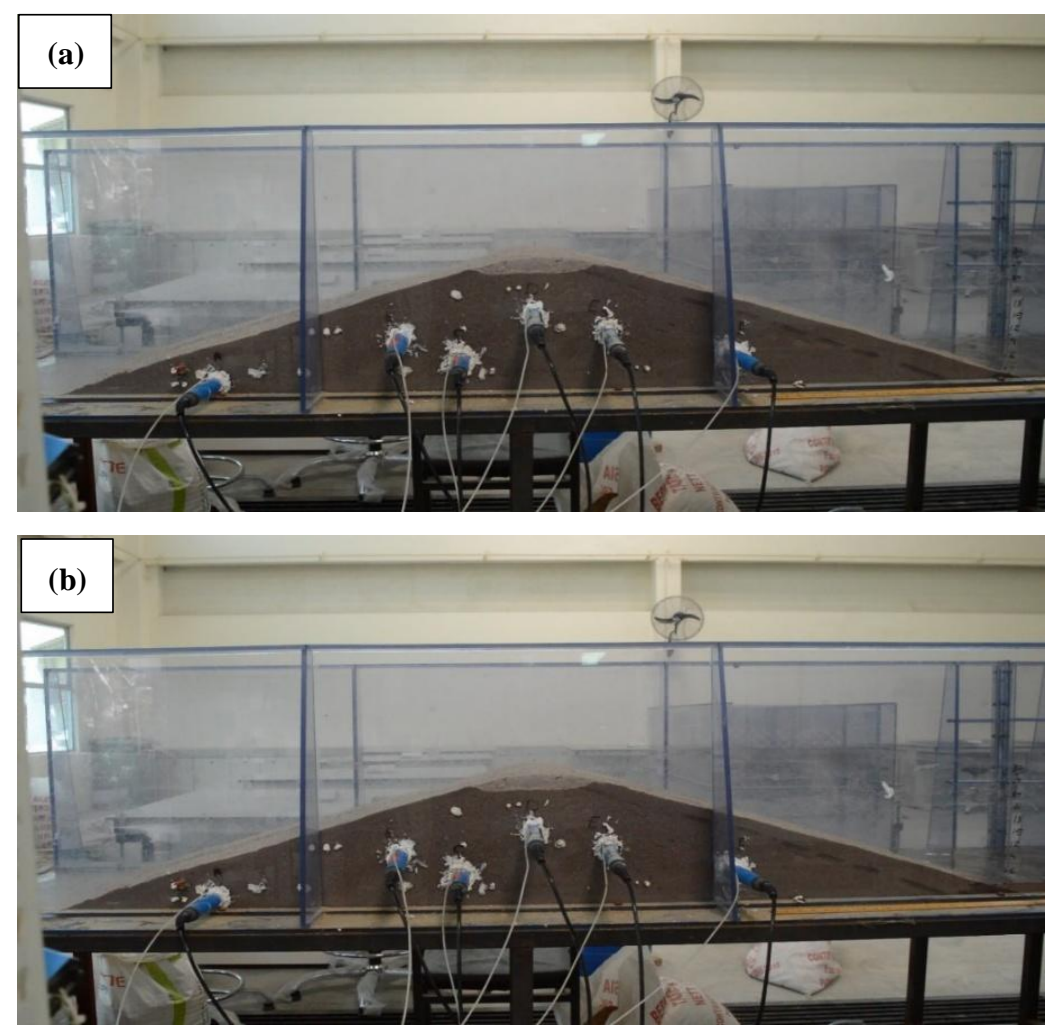

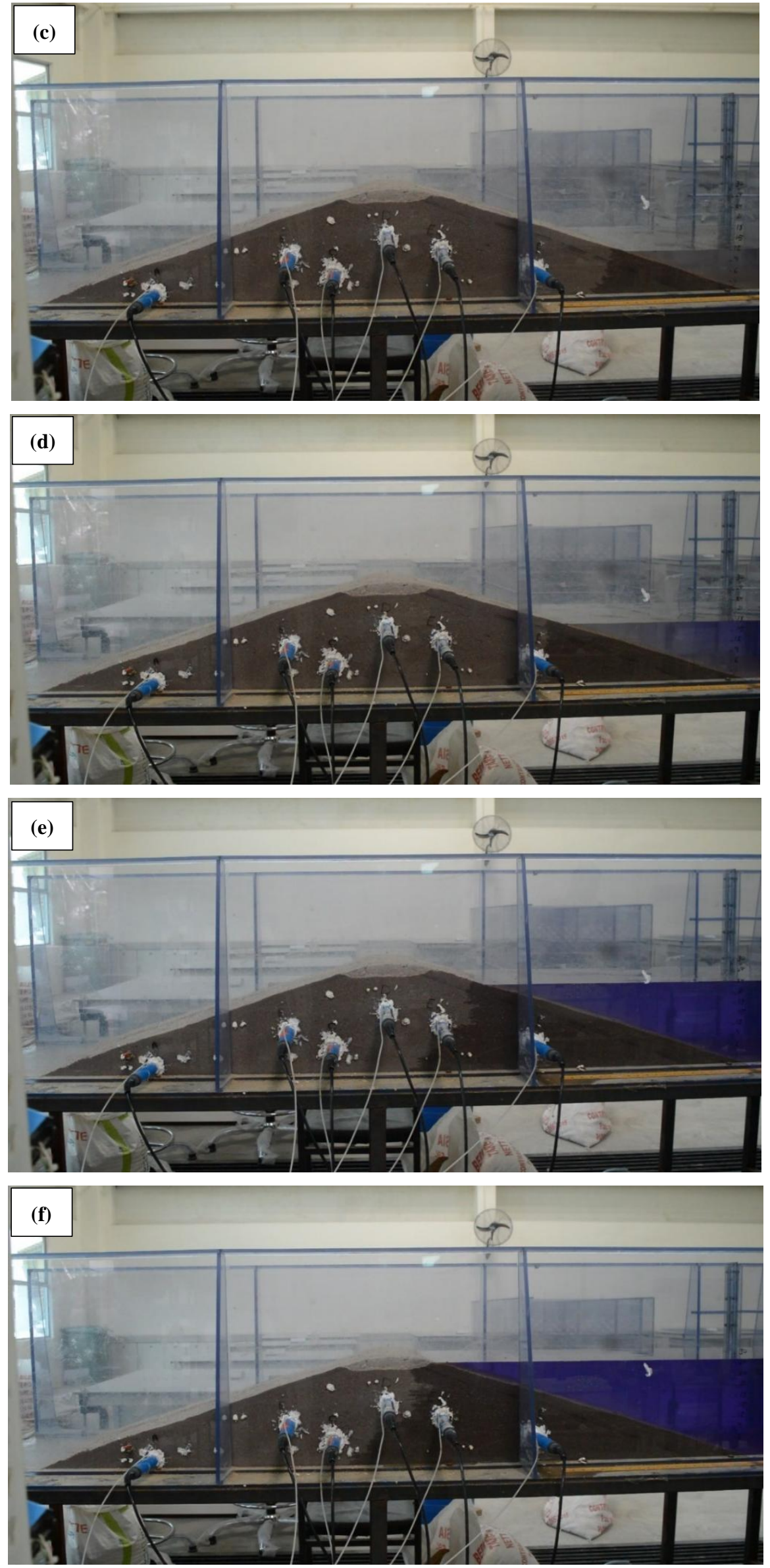

Figure 5. The actual experimental tests for the gradual water infiltration in the upstream slope for: (a) $0 \mathrm{~cm}$; (b) $3 \mathrm{~cm}$; (c) 12 cm, (d) $18 \mathrm{~cm}$; (e) $24 \mathrm{~cm}$ and (f) $27 \mathrm{~cm}$ 

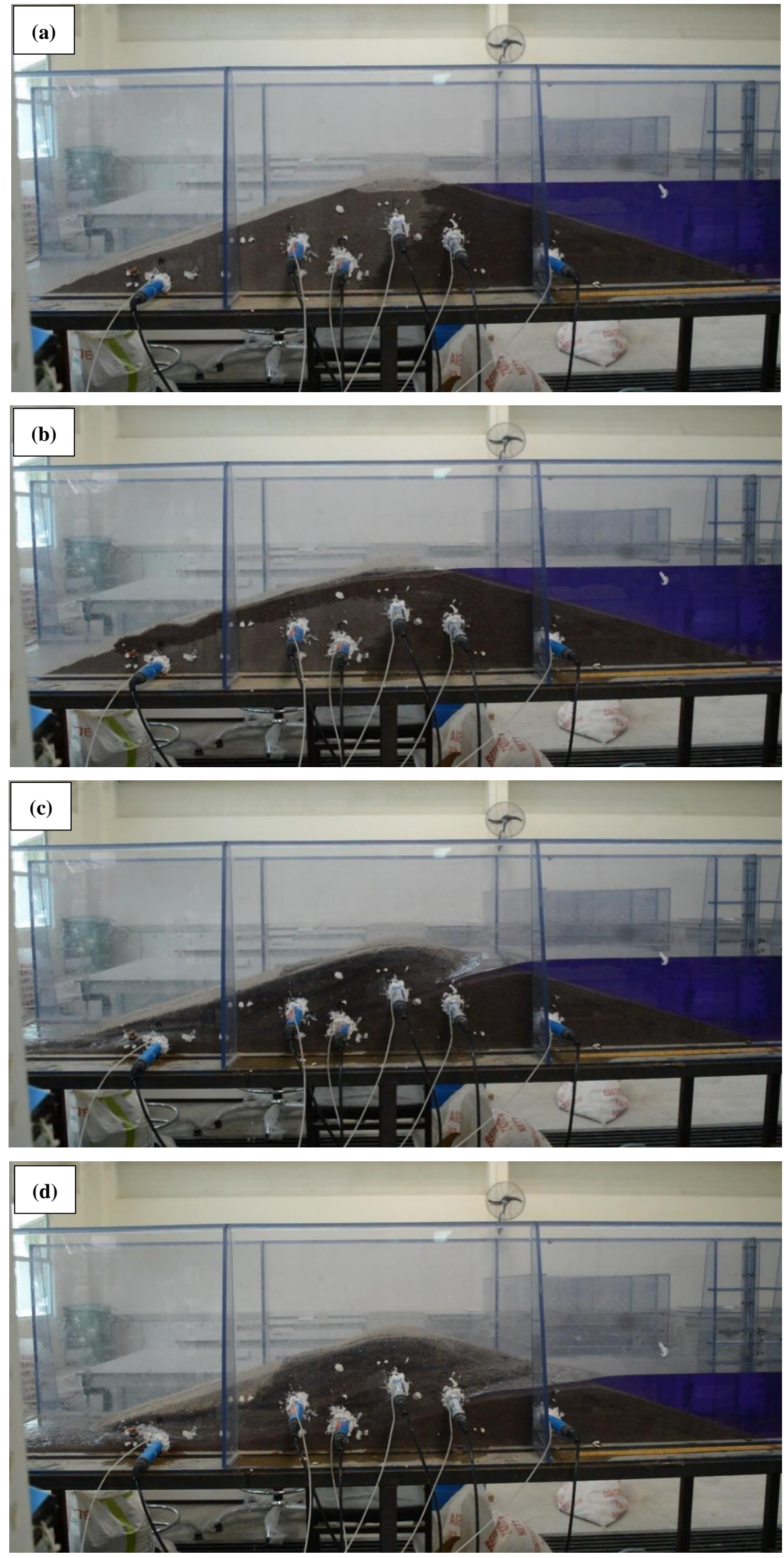


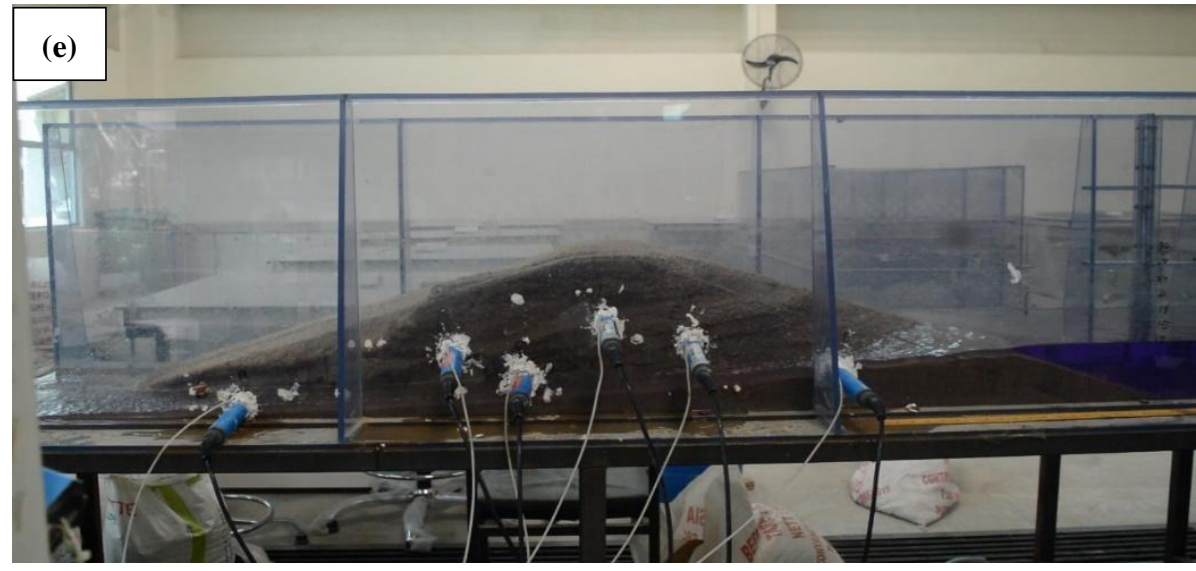

Figure 6. The actual responses of tensiometer and TDR sensor after overtopping failure for: (a) Zero seconds; (b) 20 seconds; (c) 70 seconds; (d) 110 seconds and (e) 190 seconds

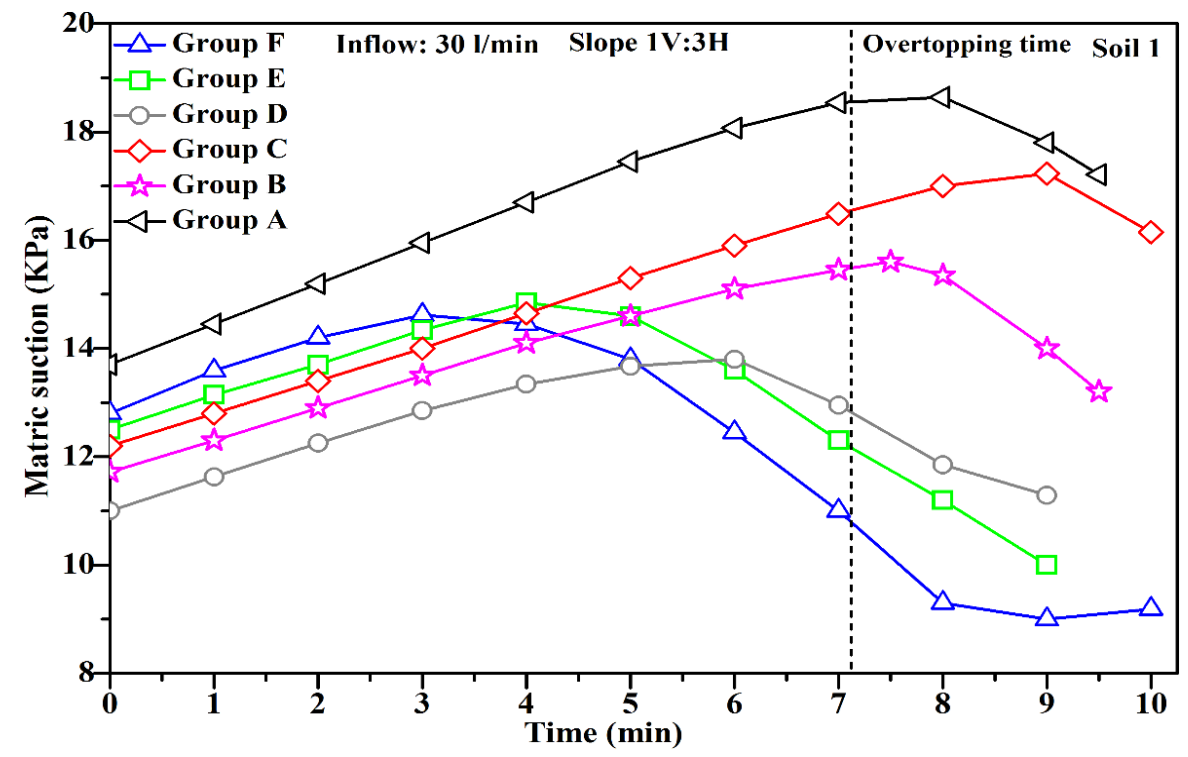

(a)

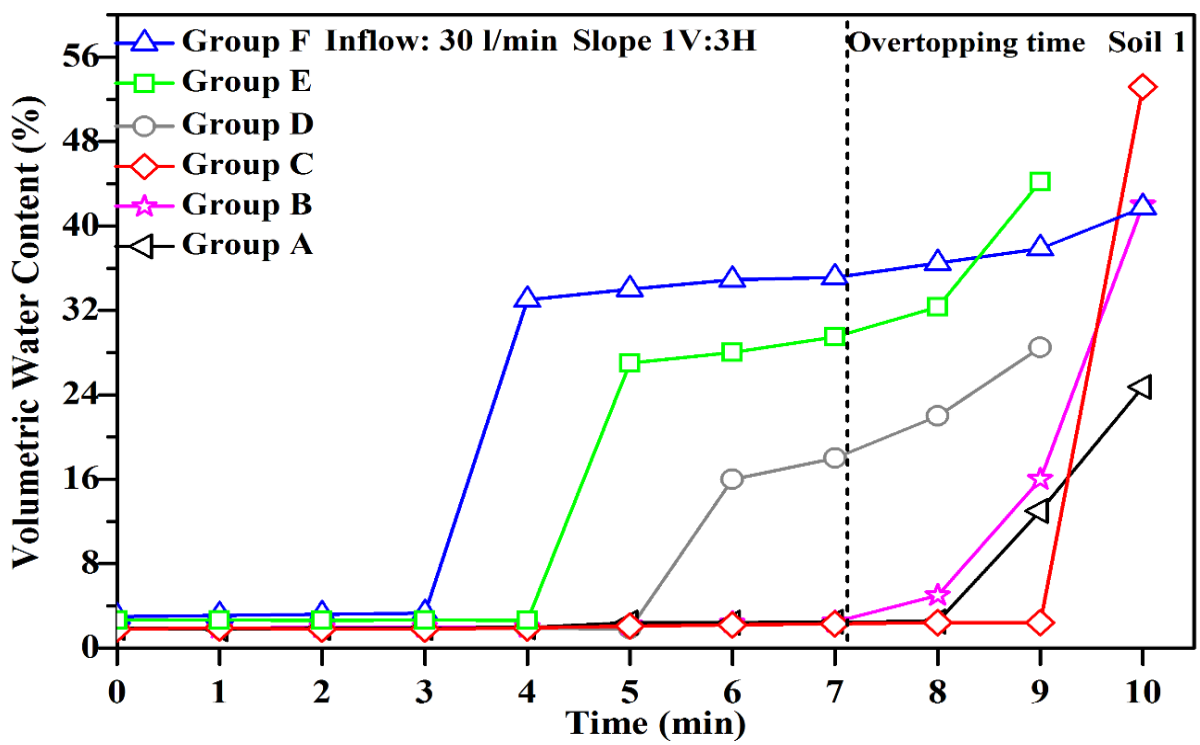

(b)

Figure 7. The group's responses of S1 during overtopping tests for a) matric suction and b) volumetric water content 


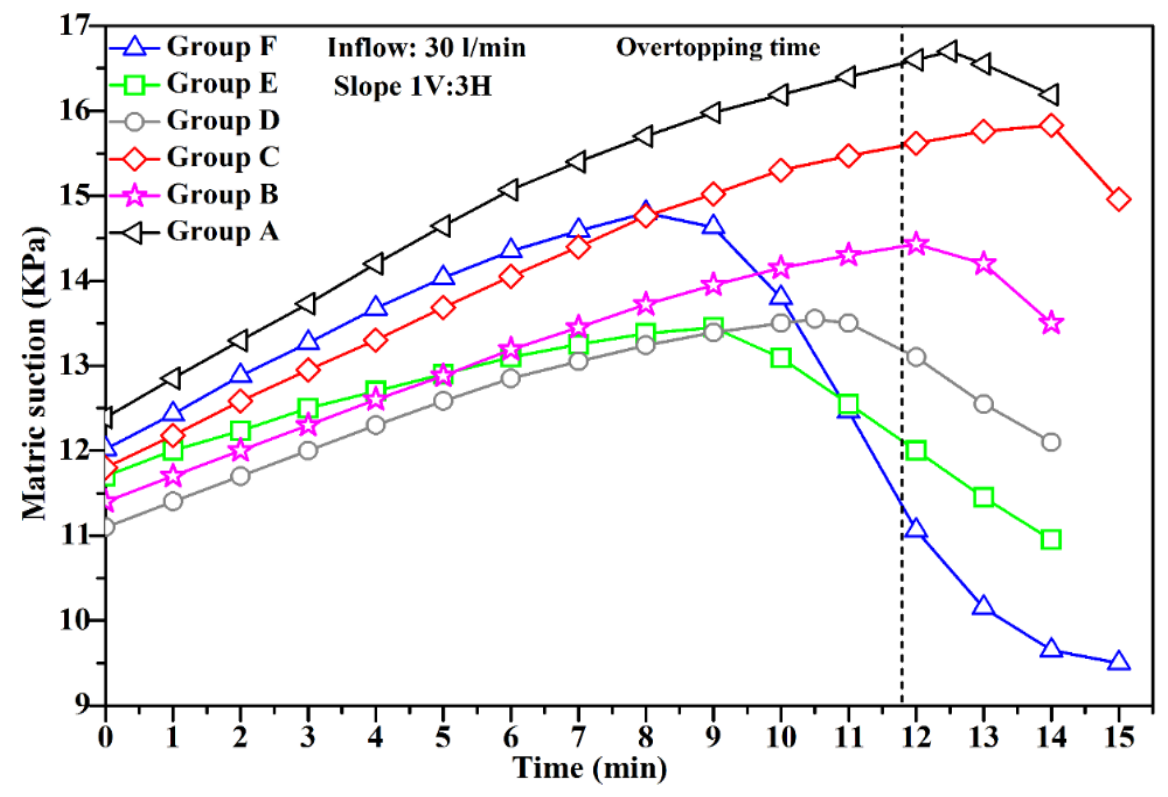

(a)

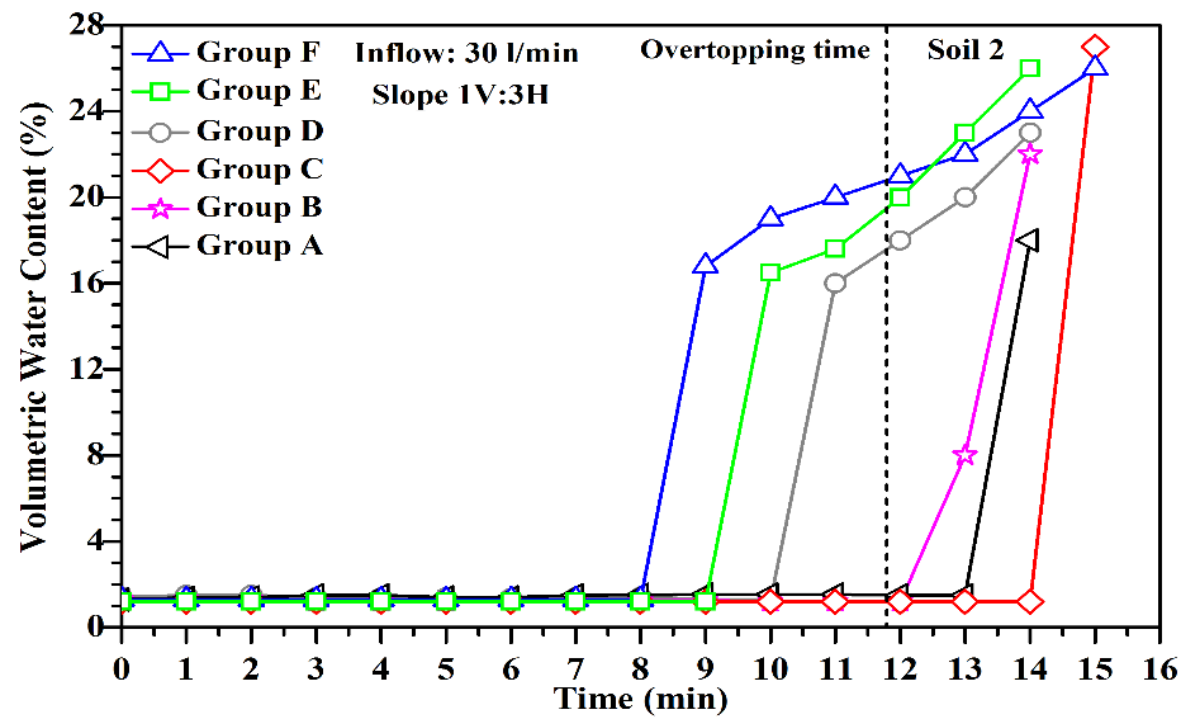

(b)

Figure 8. The group's responses of S2 during overtopping tests for a) matric suction and b) volumetric water content

However, the reductions of matric suctions show the smaller impact of infiltration water in dike before overtopping moments. The flow water near the top of upstream slope is affected slightly on the soil layer below dike slope. The breach channel in dike crest is saturated and accelerated after overtopping failure and thus increases the amount of water content inside the particles. The volumetric water content of $\mathrm{S} 1 \mathrm{is} 28.5 \%$ at $\mathrm{t}=9$ minutes while it is $18 \%$ at $\mathrm{t}=12 \mathrm{minutes}$. The increasing of water contents for both soils indicates the importance of seepage flow inside the erosion breach channel. The continuous decreasing and increasing of matric suction and volumetric water content, respectively, resulted in decreasing Factor of Safety (FOS) for dike crest, consequently the shear resistance of soil particles is failed due to high water velocity and thus the effect on dike slope instability. However, the percentage increasing and decreasing of volumetric water contents and negative pore water pressures, respectively, for S2 is less at latter minutes due to the high connection of fine particles into water molecules. The volumetric water contents are 20 and $23 \%$, while the negative pore water pressures are 13.1 and $12.55 \mathrm{kPa}$ at $\mathrm{t}=13$ and 14 minutes, respectively. The responses of groups $\mathrm{A}, \mathrm{B}, \mathrm{C}$ is noticeably affected, by infiltration water in the development pilot channel, after the overtopping failure for both S1 and $\mathrm{S} 2$. The beginning decreasing and increasing of matric suction and volumetric water content for groups A and B is faster than those in group $\mathrm{C}$ for S2. They occurred at $\mathrm{t}=14$ and 13 minutes for groups $\mathrm{A}$ and $\mathrm{B}$, respectively, and at $\mathrm{t}=15$ minutes for group $\mathrm{C}$. The matric suction and volumetric water content for group A at $\mathrm{t}=13$ minutes are $16.19 \mathrm{kPa}$ and $18 \%$ while they are $14.2 \mathrm{kPa}$ and $8 \%$, respectively for group $\mathrm{B}$ at $\mathrm{t}=13$ minutes. However, the reductions of matric suctions are faster in group B than the other two groups. This is due to the evolution of lateral and vertical erosion 
processes near the top and toe of downstream slope. The soil layers near group $\mathrm{C}$ is collapsing due to the erosion processes occurred in the transmitted area between the downstream and upstream slope. The responses of matric suction and volumetric water content is considered the longest compared with groups A, B and D in which it ended at $\mathrm{t}=15$ minutes. This is due to the ending of the erosion of dike materials near the toe of upstream slope. Figures 9 and 10 show the comparison results between the behaviors of matric suctions and volumetric water contents between S1 and S2, respectively. The very silty sand soil has a characteristic of containing fine particles which effects on the development of matric suction and volumetric water content. For groups F, the decreasing and increasing of matric suction and volumetric water content are occurring at $\mathrm{t}=4$ minutes for $\mathrm{S} 1$ while they occur at $\mathrm{t}=7$ minutes for $\mathrm{S} 2$. The infiltration water penetrates the soil particles of $\mathrm{S} 1$ faster than that for $\mathrm{S} 2$ due to the composition particles of $\mathrm{S} 2$. At $\mathrm{t}=5 \mathrm{minutes}$, the matric suctions are 13.8 and 14.03 for S1 and S2, while the volumetric water contents are 34 and $1.34 \%$, respectively. The fine particles (clay and silt) are very small and tightly gathered inside soil in which they possess huge specific areas. The inter-particles forces are connected and governed the fine particles and effect on the absorption of water content for dike soil. They decrease the permeability of infiltration water within soil particles and thus the vertical and horizontal water levels are distributed hardly near the toe of upstream slope towards group F; consequently the responses of matric suction and volumetric water content for S2 are delayed for a longer time. The reduction of matric suction is occurring pointedly in S1 compared with S2 during overtopping tests while the responses of volumetric water contents are gradually increased for S2. At $\mathrm{t}=9$ minutes, the reductions of matric suction are 9.3 and $14.36 \mathrm{kPa}$ for S1 and S2 and the volumetric water contents are 37.87 and $16.8 \%$, respectively. Despite that, the gradual increasing of volumetric water contents for S2 is slow compared with $\mathrm{S} 1$ till the end of erosion process in the upstream in which the volumetric water contents at $\mathrm{t}=11,12$ and 13 minutes are 20,21 and $22 \mathrm{kPa}$, respectively. The volumetric water contents for $\mathrm{S} 1$ are 37.87 and $41.75 \%$ at $\mathrm{t}=9$ and 10 minutes, respectively. This is due to the higher permeability of sandy soil to infiltration water that leads to decreases and increases significantly negative pore water pressure and volumetric water content, respectively.
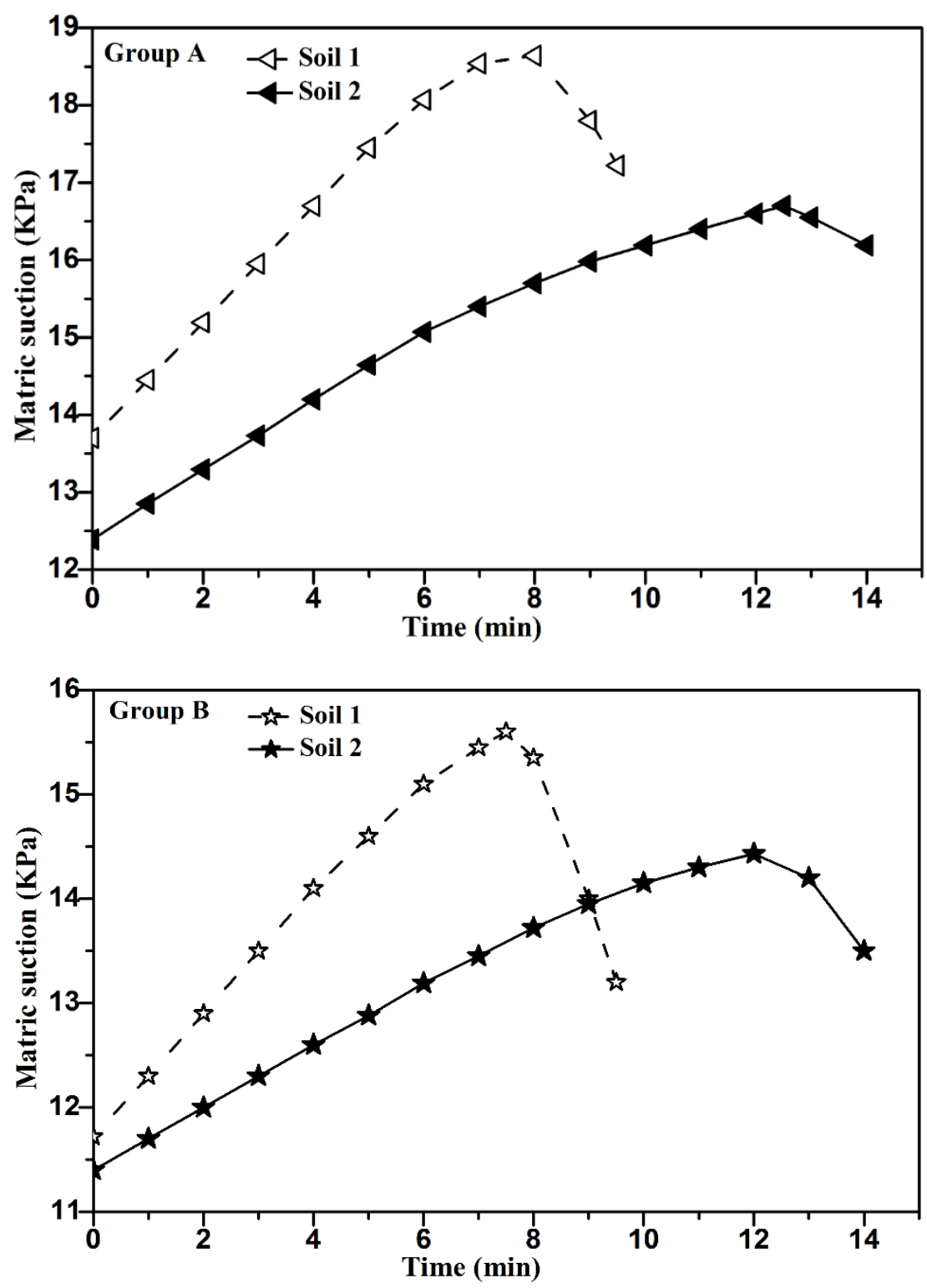

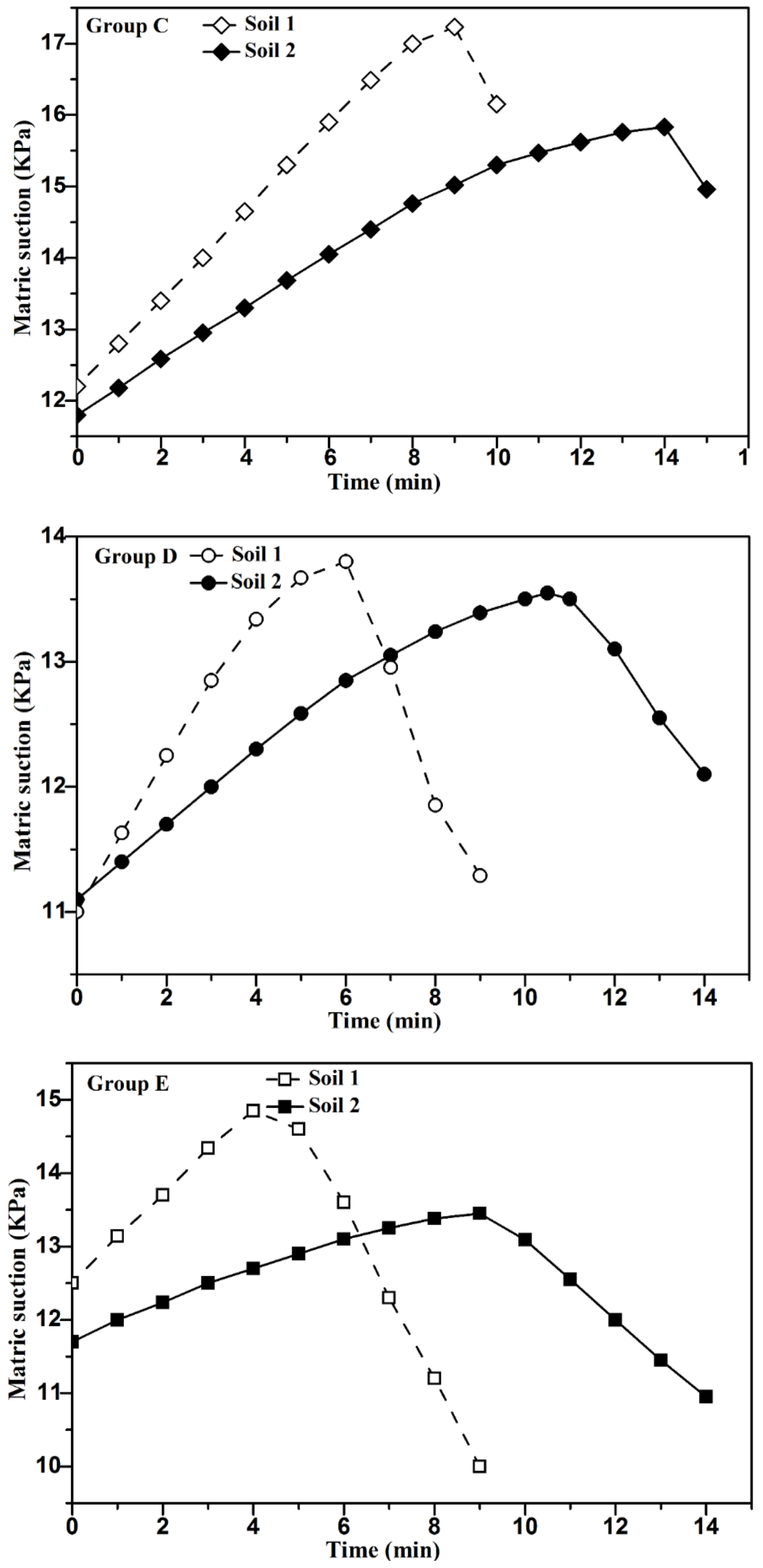


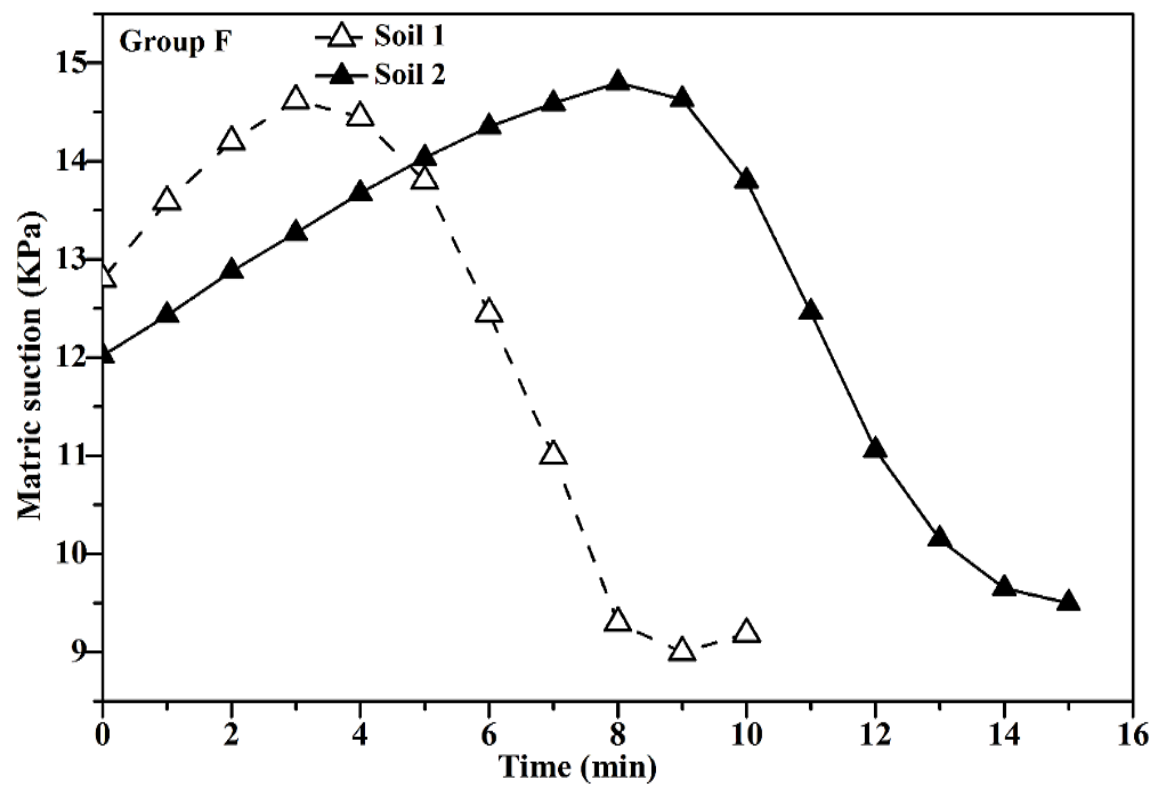

Figure 9. Comparable results of matric suctions between S1 and S2
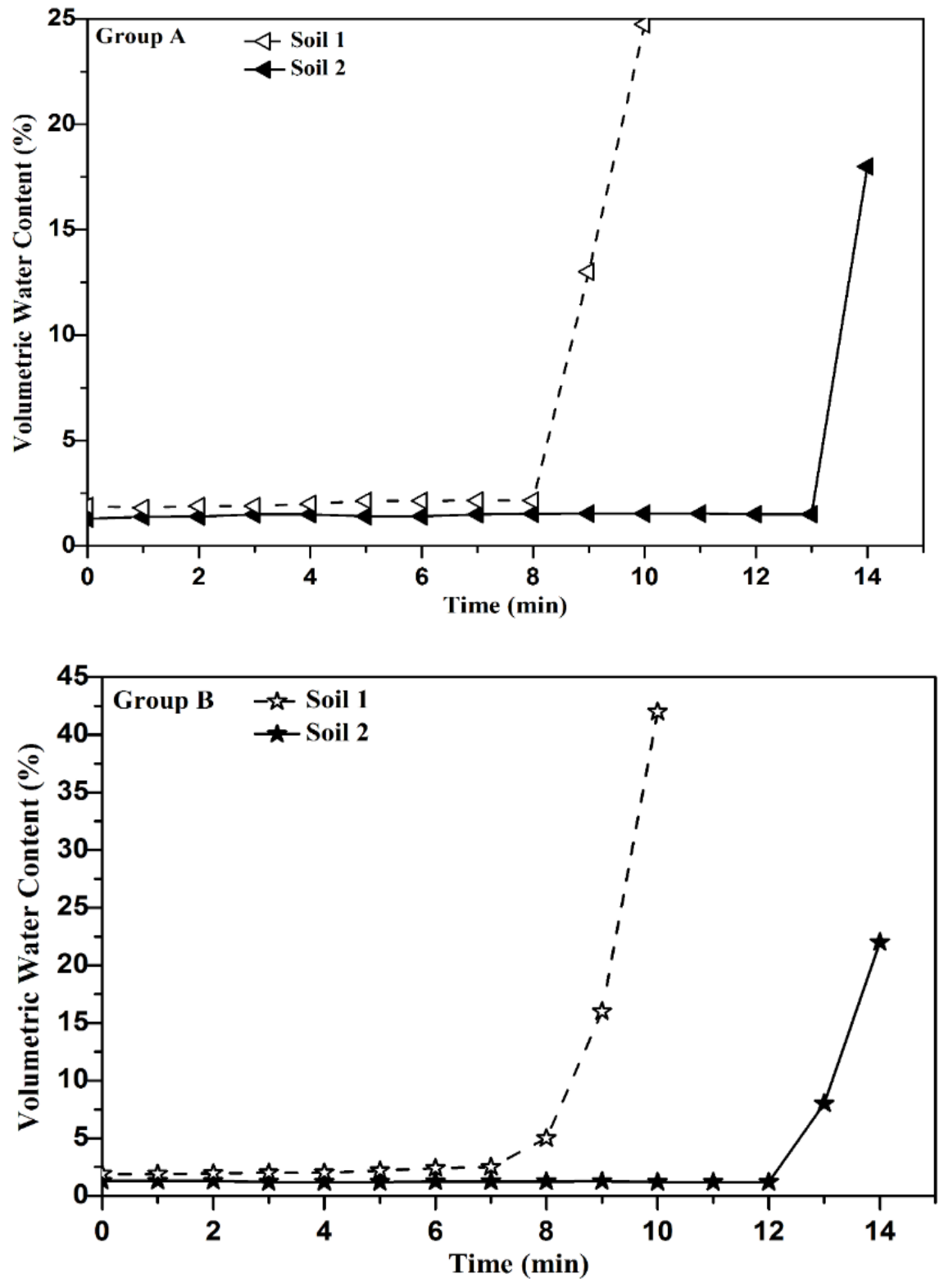

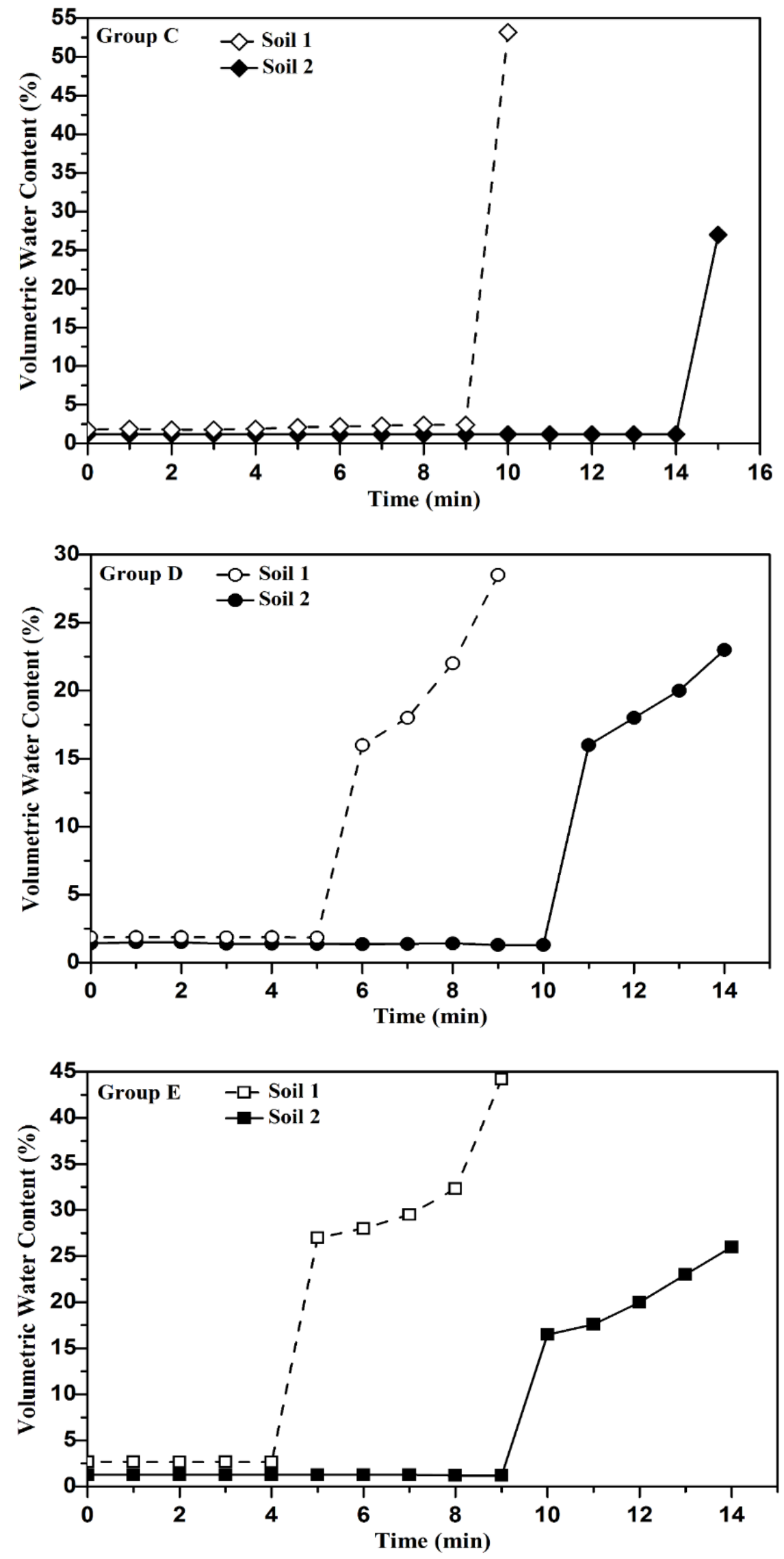


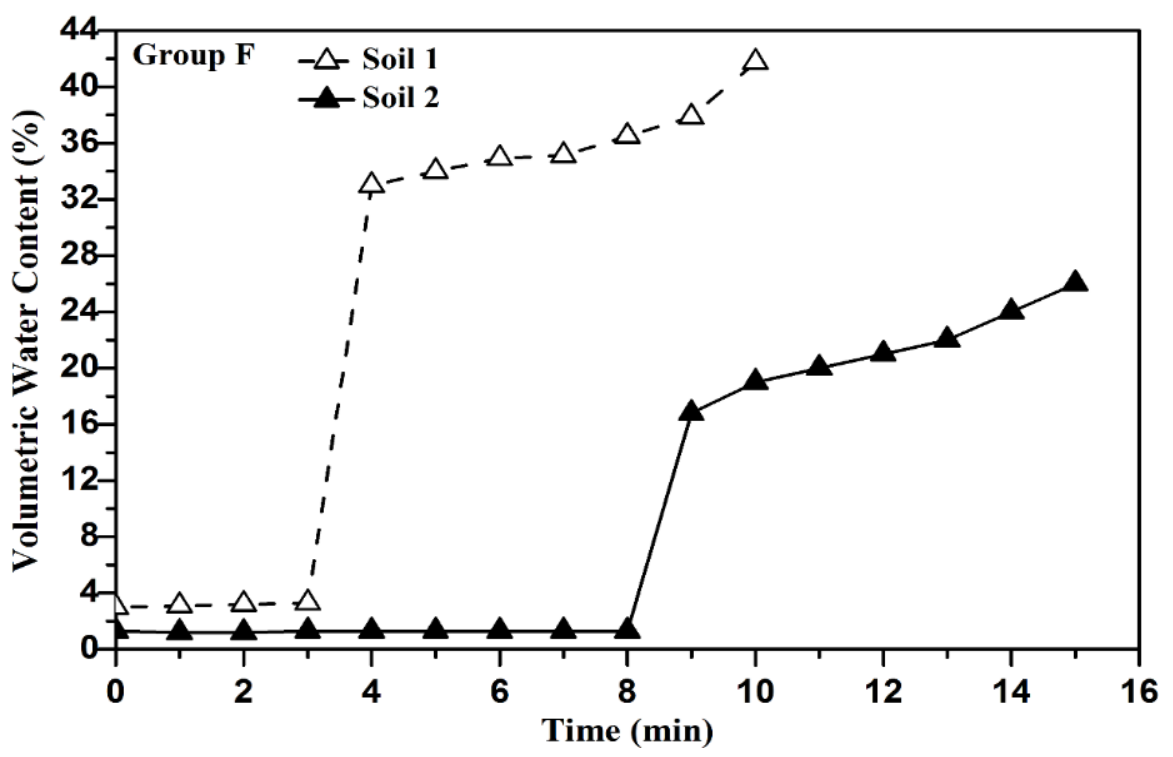

Figure 10. Comparable results of volumetric water contents between S1 and S2

The continuity of saturation process for $\mathrm{S} 1$ and $\mathrm{S} 2$ is ended at $\mathrm{t}=10$ and 15 minutes, respectively. This is due to the reduction of water velocity for very silty sand in the upstream slope and thus slow the development of the erosion process. The saturation processes for group E for S1 and S2 are occurred due to the rise of phreatic level into middle of upstream slope and thus increases the volumetric water contents inside the dike. The responses of volumetric water contents are higher for S1 than that for S2 during the whole overtopping test. This is due to the delay of transferring water infiltration into group $\mathrm{E}$ due to the restrictions of gravity and the presence of fine particles. The gravitational forces reduced the velocity of infiltration water towards the middle of upstream slope and thus more particles is saturated in horizontal direction rather than in vertical directions. The combined silica- alumina sheets in fine particles are tightly connected by hydrogen bonding inside particles and thus reduce the permeability of water for S2. The responses of matric suction and volumetric water content are continued until $\mathrm{t}=9$ and 14 minutes in which the volumetric water contents are 44.2 and $26 \%$, for S1 and S2, respectively. This is due to the longest saturation process in the transition area between downstream and upstream slopes for $\mathrm{S} 2$ that slow the duration of erosion process near group B. Comparing with group F, the increasing of volumetric water contents of group $\mathrm{E}$ is high in which the volumetric water contents are 24 and $26 \%$ at $\mathrm{t}=14$ minutes for S2. This is due to the increasing water velocity during the development of the breach channel near the middle of upstream slope.

The erosion process is continued longer for group $\mathrm{F}$ in which it lasted until $\mathrm{t}=15$ minutes. This is due to direction of vertical erosion process from the dike crest till the toe of the upstream slope. The overtopping failure occurred due to the penetration of infiltration water in the pilot channel near group $\mathrm{D}$. The saturation process is occurring faster for the layers below dike crest faster in S1 than that in S2. This is due to the increases of water turbulence inside the breach channel failure after the overtopping moment and thus increases the amount of water content inside the particles. The porosity of S1 increases the ability of soil particles to increase the infiltration of water level inside neighboring particles during the widening of the breach channel in the dike crest. The matric suction at $\mathrm{t}=8$ minutes of $\mathrm{S} 1$ is $11.85 \mathrm{kPa}$ with volumetric water content of $20 \%$. On the other hand, the matric suction is continually increasing in value of 13.24 while the responses of volumetric water content are closed to dry condition with a value of $1.42 \%$ for S2. The attached water level of the upstream slope is reached faster the dike crest for S1 higher than S1. However, the major decreasing and increasing of negative pore water pressures and volumetric water contents, respectively, for both soils are occurring after overtopping failure. The reduction and increasing of volumetric water content, respectively, for S2 are occurring slower than that in S1. The S2 has lower porosity, due to the tightly fine particle composition, in which the movement of water molecules is difficult to ease; consequently the materials are longer eroded.

The responses of negative pore water pressures and volumetric water contents for $\mathrm{S} 1$ and $\mathrm{S} 2$ are ended at $\mathrm{t}=9$ and 14 minutes, respectively. This huge difference shows the effect of seepage flow for S1 in the upstream slope that contribute to the erosion process in the downstream slope. The presence of fine particles of S2 reduces the velocity of horizontal and vertical erosion process in the transition area between the downstream and upstream slope, thus the shear strength parameter for most voids in the upstream slope still resists the overtopping flow inside breach channel. The reduction of matric suctions, for $\mathrm{S} 1$, is occurring at $\mathrm{t}=10$ minutes in which the percentage of water content within particles are $53.2 \%$ for group C. For S2, the responses of volumetric water content are delayed until $\mathrm{t}=15$ minutes with a value of $27 \%$. This is due to the development of lateral and vertical erosion processes in the transition area between upstream and downstream slopes. The higher coarse particles in S1 increases the rate of breach channel failure and thus 
increases the quantity of volumetric water content near group C. For S1 and S2, the responses of matric suctions and volumetric water contents are close to dry conditions (water content $=$ zero) during most experimental test's time until $\mathrm{t}$ $=10$ and 15 minutes, respectively. This indicates the reduction of FOS for soil layers below dike crest that accelerates the failure of the pilot channel near group $\mathrm{C}$. The responses of matric suctions and volumetric water contents for groups $\mathrm{A}$ and $\mathrm{B}$ are occurring during the erosion process in the downstream slope for both S1 and S2. In group B, the beginning reduction of matric suctions for $\mathrm{S} 1$ and $\mathrm{S} 2$ is not high at $\mathrm{t}=8$ and 13 minutes, respectively. This is due to the less connection to infiltration water, towards the downstream slope region, during the water flow cross above the dike crest inside the pilot channel.

The velocity of water has accelerated the increasing rate of the volumetric water content within particles during the transition of overtopping flow from the top into the toe of the downstream slope in S1. Increasing the water content leads to reduce the critical shear stress along the dike slope and thus resulted in dike slope instability. The volumetric water contents are 16 and $1.26 \%$ for S1 and S2, respectively at $t=9$ minutes. The cohesive forces of S2 increase the negative pore water pressure and thus increases the shear strength for longer time, compared with $\mathrm{S} 1$, against the power of water flow erosion in which the erosion process ended at $t=13$ minutes. The responses of volumetric water contents are occurring earlier at $\mathrm{t}=13$ minutes compared with that for group $\mathrm{C}$. This is due to the locations of group B near the upper part of downstream slope that ease the water infiltration process in which the water velocity starts to be accelerated. The highest overtopping water velocity inside breach channel is occurring near the region of group A in which the water conditions changed from critical into subcritical and thus increased the volumetric water content. The high volumetric water for $\mathrm{S} 2$, occurred at $\mathrm{t}=14$ minutes, is considered the lowest compared with other group results in which the volumetric water content is $18 \%$. This is due to the beginning of erosion process near the bed of dike construction in the downstream slope and then extended into middle and upstream slope and thus the responses of volumetric water content and matric suction are ended early. Figures 11 and 12 show the vertical erosion process inside the dike embankment for S1 and S2, respectively. The dashed line represents the paths of vertical erosion process during the development of breach channel.

The vertical erosion process is initiated through crossing flow water in the pilot channel at $\mathrm{t}=$ zero seconds. At $\mathrm{t}=$ 10 seconds, the vertical erosion processes in both soils is small due to high materials quantity in the dike crest and the lack of water content percentage in the downstream slope. The development of breach channel in the downstream slope is occurring at latter minutes due to the increase of water velocity and turbulence. At $t=80$ and 180 seconds, the majority of downstream slope materials are eroded for S1 and S2, respectively in which the breach channel failure is developed in the transition area between downstream and upstream slopes and area of the upstream slope. Soils with higher fine particles are helped to stick particles together and thus reduce the rate of infiltration water and time of erosion materials. The enlargement of vertical breach channel is slow down gradually and then stopped, due to the reduction of erosion velocity, while most of dike crest height is disappearing at $\mathrm{t}=190$ and 690 minutes for S1 and S2, respectively.

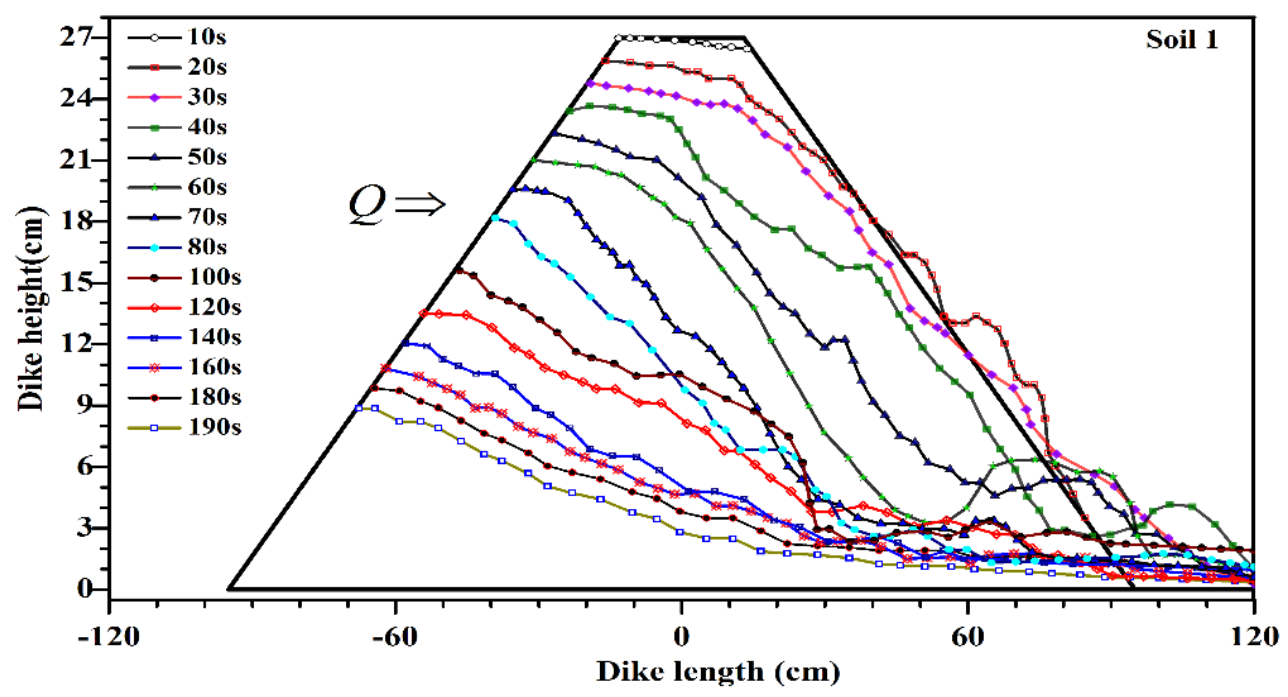

Figure 11. Dike breach profiles for vertical erosion process of S1 


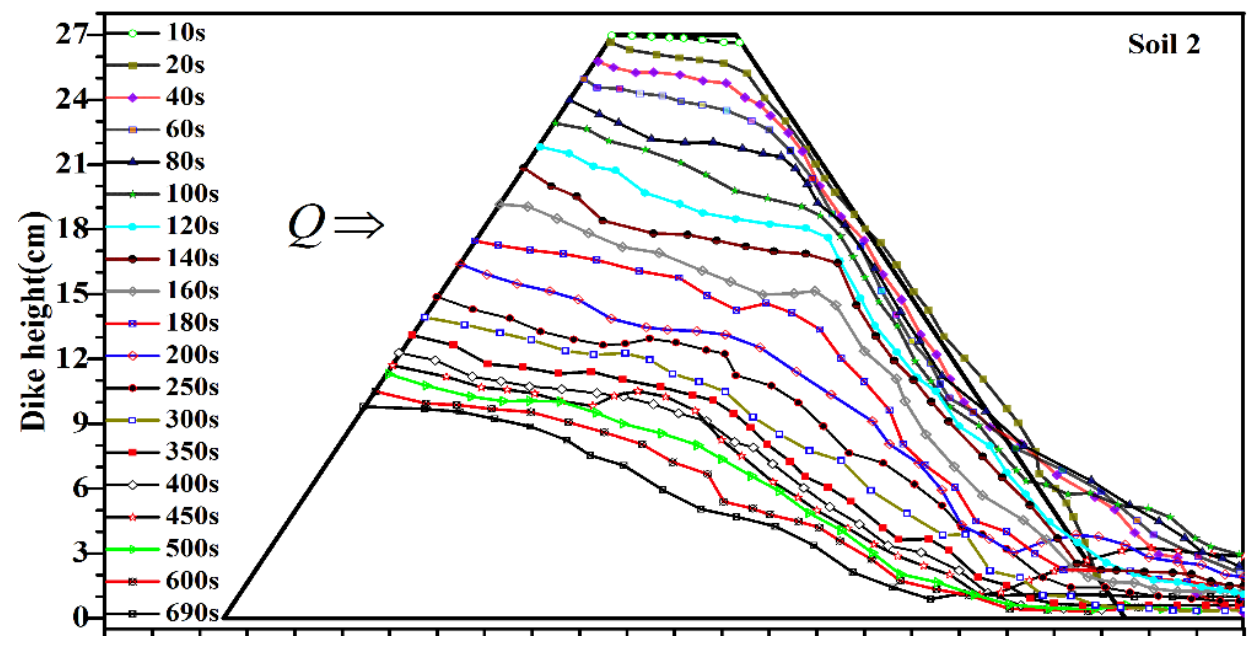

Figure 12. Dike breach profile for vertical erosion process of S2

\section{Conclusion}

Two overtopping tests are discussed in this paper to evaluate the effect of sand and very silty sand soils on the development on matric suction and volumetric water content for six groups using twelve tensiometer and TDR sensors, respectively. The tests were conducted in small flume channel in Hydraulic Geotechnical laboratories at the Universiti Sains of Malaysia. The dimensions of dike embankment and inflow discharge of $30 \mathrm{l} / \mathrm{min}$ are similar for both tests. The results show that the reduction of matric suctions occurred as a result of infiltration water inside soil particles and thus increases the volumetric water contents in both soils. The groups sensors in the upstream slope tend to be saturated early compared with those in the middle and downstream slope of dike embankment during the transition of phreatic water level from the upstream slope into downstream slope through pilot channel. The rate of decreasing and increasing of matric suctions and volumetric water contents, respectively are lower in very silty sand soil than those in sandy soil due to the presence of fine particles in previous soil. The permeability of very silty sand soil reduce the velocity of erosion process within dike particles.

\section{References}

[1] Jansen. "Advanced dam engineering for design, construction, and rehabilitation, First Edition" (December 31, 1988). doi: 10.1007/978-1-4613-0857-7.

[2] Bahattari Kumar, Nakagawa Hajimi, Kawaike Kenji, Zhang Hao. "Experimental study on effect of sediment size on river dyke breach characteristics due to overtopping." Japan Society for Natural Disaster Science 33 (June 2014): 65-74.

[3] Marwan Adil Hassan, Mohd Ashraf Mohd Ismail." Literature Review for the Development of Dike's Breach Channel Mechanism Caused By Erosion Processes during Overtopping Failure". Engineering Heritage Journal / Galeri Warisan Kejuruteraan 1(November 2017):23-30. doi: 10.26480/gwk.02.2017.23.30 .

[4] Giuseppe Buscarnera, Claudio Di Prisco (2013). "Soil stability and flow slides in unsaturated shallow slopes: can saturation events trigger liquefaction processes?'. Géotechnique 63 (August 2013): $801-817$.

[5] Singh Vijay, and Quiroga Cesar." Dimensionless analytical solutions for dam-breach erosion" Journal of Hydraulic Research 26 (September 1988): 179-197. doi: 10.1080/00221688809499224.

[6] Singh Vijay, and Scarlatos panagiotis. "Analysis of gradual earth-dam failure" Journal of Hydraulic Engineering 114 (January 1988): 21-42. doi: 10.1061/(asce)0733-9429(1988)114:1(21)

[7] Rico Mayte, Benito Gerardo, and Diez-Herrero, Andres. "Floods from tailings dam failures" Journal of Hazardous Materials 154 (June 2008): 79-87.doi: https://doi.org/10.1016/j.jhazmat.2007.09.110.

[8] Rui Hui, Elizabeth Jachens, and Jay Lund." Risk-based planning analysis for a single levee", Water Resources Research 52 (April 2016): 2513-2528, doi:10.1002/ 2014WR016478.

[9] Henrik Madsen, Deborah Lawrence, Michel Lang." Review of trend analysis and climate change projections of extreme precipitation and floods in Europe" Journal of Hydrology 519 (November 2014): 3634-3650. doi: 10.1016/j.jhydrol.2014.11.003.

[10] Stefano Orlandini, and John Albertson. "Evidence of an emerging levee failure mechanism causing disastrous floods in Italy". Water Resources Research 51 (October 2015): 7995-8011. doi: 10.1002/2015WR017426.

[11] Sheng long Gu, Liqun Ren, Xing Wang, Hongwei Xie, Yuefei Huang, Jiahua Wei, and and Song dong Shao. "SPHysics Simulation of Experimental Spillway Hydraulics". Water 9 (December 2017): 1-19. doi: 10.3390/w9120973.

[12] Costa John, and Schuster Robert. "The formation and failure of natural dams". Bulletin of the Geological Society of America 100 (July 1988):1054-1068. doi: 10.1130/0016-7606(1988)100<1054:TFAFON>2.3.CO;2. 
[13] Steetzel Henk and Visser, Paul. "Profile development of dunes due to overflow" Proceedings of the International Conference of Coastal Engineering, Venice, (1992). doi: 10.1061/9780872629332.203.

[14] Lindsey Ann Larocque, Jasim Imran and M. Hanif Chaudhry. "3D numerical simulation of partial breach dam-break flow using the LES and k-€ turbulence models". Journal of Hydraulic Research 51(March 2013): 145-157. doi: 10.1080/00221686.2012.734862.

[15] Sylvie Van Emelen, Yves Zech, and Sandra Soares-Frazao. "Impact of sediment transport formulations on breaching modelling". Journal of Hydraulic Research 53(October 2015): 60 - 72. doi: 10.1080/00221686.2014.939111.

[16] Takaharu Kakinuma, and Yasuyuki Shimizu. "Large-scale experiment and numerical modelling of a riverine levee breach". Journal of Hydraulic Engineering 140(September 2014): 1-9. doi: 10.1061/(ASCE)HY.1943-7900.0000902.

[17] Ming-hui Yu, Hongyan Wei, Yan-jie Liang, Yong zhao. "Investigation of non-cohesive levee breach by overtopping flow". Journal of Hydrodynamics 25 (September 2013): 572-579. doi: 10.1016/S1001-6058(11)60398-4.

[18] Hongyan Wei, Minghui Yu, Dangwei Wang, and Yitian L." Overtopping breaching of river levees constructed with cohesive sediments". Natural Hazards and Earth System Sciences 16 (July 2016): 1541-1551. doi: 10.5194/nhess-16-1541-2016.

[19] Bryan Orendorff, Mahmoud Al-Riffai, Ioan Nistor, Colin D. Rennie. (2013). "Breach outflow Characteristics of non-cohesive embankment dams subject to blast". Canadian Journal of Civil Engineering 40(January 2013): 243-253. doi: 10.1139/cjce-2012-0303.

[20] Hanson Gregory, and Hunt Sherry. "Lessons learned using laboratory JET method to measure soil erodibility of compacted soils" Applied Engineering in Agriculture 23(May 2007): 305-312. doi: 10.13031/2013.22686.

[21] Gaucher Jeremie, Marche Claude. and Mahdi Tew. "Experimental investigation of the hydraulic erosion of non-cohesive compacted soils" Journal of Hydraulic Engineering 136 (May 2010): 901-913.doi: 10.1061/(ASCE)HY.1943-7900.0000274.

[22] Hahn William, Hanson Gregory and and Cook Kevin. "Breach Morphology Observations of Embankment Overtopping Tests" Proceedings of the Joint Conference on Water Resources Engineering and Water Resources Planning and Management, Minneapolis, (2000). doi: 10.1061/40517(2000)411.

[23] Hunt S.L, Hanson G.J, Cook K.R, and Kadavy K.C. "Breach widening observations from earthen embankment tests" Transactions of the ASAE 48(April 2005). doi: 10.13031/2013.16212.

[24] Geisenhainer, P. and Kortenhaus, Andreas. "Hydraulic model tests on breaching with and without waves: Description of experiment performed at LWI" FLOOD site Report T06- 06-02 (Revision 2_6_03), Germany, (2009).

[25] Pickert Gerd, Weitbrecht Volker, and Bieberstein A. "Breaching of overtopped river embankments controlled by apparent cohesion" Journal of Hydraulic Research 49 (May 2011):143-156. doi: 10.1080/00221686.2011.552468.

[26] Coleman Stephen, Andrews Darryl, and Webby Grant. "Overtopping breaching of non-cohesive homogeneous embankments" Journal of Hydraulic Engineering 128(August 2002): 829-838. doi: 10.1061/(ASCE)0733-9429(2002)128:9(829).

[27] Stretch Derek, and Parkinson Michael. "The breaching of sand barriers at perched, temporary, open/closed estuaries - A model study" Coastal Engineering Journal 48 (January 2006); 13-30. doi: 10.1142/s0578563406001295.

[28] Parkinson Michael, and Stretch Derek. "Breaching timescales and peak outflows for perched, temporary open estuaries" Coastal Engineering Journal 49(September 2007): 267-290. doi: 10.1142/s0578563407001605.

[29] Pickert Gerd, Jirka G.H, Bieberstein Andreas, and Brauns J. "Soil/water interaction during the breaching process of overtopped embankments" Proceedings of the 2nd International Conference on River Flow, Naples, (2004). doi: 10.1201/b16998-115.

[30] Marwan A. Hassan, and Mohd A. M. Ismail. "Effect of inflow discharges on the development of matric suction and volumetric water content for dike during overtopping tests" Proceeding of American Institute of Physics conferences, Penang, (2017). doi: $10.1063 / 1.5005675$.

[31] Marwan A. Hassan, Mohd A. M. Ismail. "Effect of Dike Slope on the Development of Matric Suction and Volumetric Water Content during Overtopping Tests". International Journal of Civil Engineering and Technology 9 (January 2018):253-262. 